HIGHLIGHTS OF PRESCRIBING INFORMATION

These highlights do not include all the information needed to use GENVOYA safely and effectively. See full prescribing information for GENVOYA.

GENVOYA ${ }^{\circledR}$ (elvitegravir, cobicistat, emtricitabine, and tenofovir alafenamide) tablets, for oral use

Initial U.S. Approval: 2015

WARNING: LACTIC ACIDOSIS/SEVERE HEPATOMEGALY WITH STEATOSIS and POST TREATMENT ACUTE EXACERBATION OF HEPATITIS B

See full prescribing information for complete boxed warning.

- Lactic acidosis and severe hepatomegaly with steatosis, including fatal cases, have been reported with the use of nucleoside analogs. (5.1)

- GENVOYA is not approved for the treatment of chronic hepatitis $B$ virus (HBV) infection. Severe acute exacerbations of hepatitis $B$ have been reported in patients who are coinfected with HIV-1 and HBV and have discontinued products containing emtricitabine and/or tenofovir disoproxil fumarate (TDF), and may occur with discontinuation of GENVOYA. Hepatic function should be monitored closely in these patients. If appropriate, initiation of anti-hepatitis B therapy may be warranted. (5.2)

\section{Contraindications (4)}

\section{RECENT MAJOR CHANGES}

Warnings and Precautions, Bone Loss and Mineralization Defects (5.7) [removed]

$09 / 2016$

INDICATIONS AND USAGE

GENVOYA is a four-drug combination of elvitegravir, an HIV-1 integrase strand transfer inhibitor (INSTI), cobicistat, a CYP3A inhibitor, and emtricitabine and tenofovir alafenamide (TAF), both HIV1 nucleoside analog reverse transcriptase inhibitors (NRTIs) and is indicated as a complete regimen for the treatment of HIV-1 infection in adults and pediatric patients 12 years of age and older weighing at least $35 \mathrm{~kg}$ who have no antiretroviral treatment history or to replace the current antiretroviral regimen in those who are virologicallysuppressed (HIV-1 RNA less than 50 copies per $\mathrm{mL}$ ) on a stable antiretroviral regimen for at least 6 months with no history of treatment failure and no known substitutions associated with resistance to the individual components of GENVOYA. (1)

\section{DOSAGE AND ADMINISTRATION}

- Testing: Prior to initiation of GENVOYA, patients should be tested for hepatitis B virus infection. Assess serum creatinine, serum phosphorous, estimated creatinine clearance, urine glucose, and urine protein before initiating GENVOYA and during therapy in all patients as clinically appropriate. (2.1)

- Recommended dosage: One tablet taken orally once daily with food in patients 12 years old and older with body weight at least $35 \mathrm{~kg}$ and a creatinine clearance greater than or equal to $30 \mathrm{~mL}$ per minute. (2.2)

- Renal impairment: GENVOYA is not recommended in patients with estimated creatinine clearance below $30 \mathrm{~mL}$ per minute. (2.3)

- Hepatic impairment: GENVOYA is not recommended in patients with severe hepatic impairment. (2.4)
DOSAGE FORMS AND STRENGTHS

Tablets: $150 \mathrm{mg}$ of elvitegravir, $150 \mathrm{mg}$ of cobicistat, $200 \mathrm{mg}$ of emtricitabine, and $10 \mathrm{mg}$ of tenofovir alafenamide. (3)

\section{CONTRAINDICATIONS}

Coadministration of GENVOYA is contraindicated with drugs that

- Are highly dependent on CYP3A for clearance and for which elevated plasma concentrations are associated with serious adverse events. (4)

- Strongly induce CYP3A, which may lead to lower exposure of one or more components and loss of efficacy of GENVOYA and possible resistance. (4)

\section{-WARNINGS AND PRECAUTIONS}

- Risk of adverse reactions or loss of virologic response due to drug interactions: The concomitant use of GENVOYA and other drugs may result in known or potentially significant drug interactions, some of which may lead to loss of therapeutic effect of GENVOYA and possible development of resistance; and possible clinically significant adverse reactions from greater exposures of concomitant drugs. (5.3)

- Redistribution/accumulation of body fat: Observed in patients receiving antiretroviral therapy. (5.4)

- Immune reconstitution syndrome: May necessitate further evaluation and treatment. (5.5)

- New onset or worsening renal impairment: Assessment of serum creatinine, serum phosphorus, estimated creatinine clearance, urine glucose, and urine protein is recommended before initiating GENVOYA therapy and during therapy as clinically appropriate. (5.6)

ADVERSE REACTIONS

Most common adverse reaction (incidence greater than or equal to $10 \%$, all grades) is nausea. (6.1)

To report SUSPECTED ADVERSE REACTIONS, contact Gilead Sciences, Inc. at 1-800-GILEAD-5 or FDA at 1-800-FDA-1088 or www.fda.gov/medwatch.

DRUG INTERACTIONS

- GENVOYA should not be administered with other antiretroviral medications for treatment of HIV-1 infection. (7.1)

- GENVOYA can alter the concentration of drugs metabolized by CYP3A or CYP2D6. Drugs that induce CYP3A can alter the concentrations of one or more components of GENVOYA. Consult the full prescribing information prior to and during treatment for potential drug-drug interactions. $(4,7.2,7.3,12.3)$

\section{USE IN SPECIFIC POPULATIONS}

- Lactation: Women infected with HIV should be instructed not to breastfeed due to the potential for HIV transmission. (8.2)

- Pediatrics: Not recommended for patients less than 12 years of age or weighing less than $35 \mathrm{~kg}$. (8.4)

See 17 for PATIENT COUNSELING INFORMATION and FDA-approved patient labeling. 


\section{FULL PRESCRIBING INFORMATION: CONTENTS*}

WARNING: LACTIC ACIDOSIS/SEVERE HEPATOMEGALY WITH STEATOSIS and POST TREATMENT ACUTE EXACERBATION OF HEPATITIS B

1 INDICATIONS AND USAGE

2 DOSAGE AND ADMINISTRATION

2.1 Testing Prior to Initiation and During Treatment with GENVOYA

2.2 Recommended Dosage

2.3 Not Recommended in Patients with Severe Renal Impairment

2.4 Not Recommended in Patients with Severe Hepatic Impairment 3 DOSAGE FORMS AND STRENGTHS

\section{CONTRAINDICATIONS}

5 WARNINGS AND PRECAUTIONS

5.1 Lactic Acidosis/Severe Hepatomegaly with Steatosis

5.2 Severe Acute Exacerbation of Hepatitis B in Patients Coinfected with HIV-1 and HBV

5.3 Risk of Adverse Reactions or Loss of Virologic Response Due to Drug Interactions

5.4 Fat Redistribution

5.5 Immune Reconstitution Syndrome

5.6 New Onset or Worsening Renal Impairment

\section{ADVERSE REACTIONS}

6.1 Clinical Trials Experience

\section{DRUG INTERACTIONS}

7.1 Not Recommend with Other Antiretroviral Medications

7.2 Potential for GENVOYA to Affect Other Drugs

7.3 Potential for Other Drugs to Affect One or More Components of GENVOYA

7.4 Drugs Affecting Renal Function

7.5 Established and Other Potentially Significant Interactions

7.6 Drugs without Clinically Significant Interactions with GENVOYA
8 USE IN SPECIFIC POPULATIONS
8.1 Pregnancy
8.2 Lactation
8.4 Pediatric Use
8.5 Geriatric Use
8.6 Renal Impairment
8.7 Hepatic Impairment

10 OVERDOSAGE

11 DESCRIPTION

12 CLINICAL PHARMACOLOGY

12.1 Mechanism of Action

12.2 Pharmacodynamics

12.3 Pharmacokinetics

12.4 Microbiology

\section{NONCLINICAL TOXICOLOGY}

13.1 Carcinogenesis, Mutagenesis, Impairment of Fertility

13.2 Animal Toxicology and/or Pharmacology

14 CLINICAL STUDIES

14.1 Description of Clinical Trials

14.2 Clinical Trial Results in HIV-1 Treatment-Naïve Subjects

14.3 Clinical Trial Results in HIV-1 Virologically-Suppressed Subjects Who Switched to GENVOYA

14.4 Clinical Trial Results in HIV-1 Infected Subjects with Renal Impairment

14.5 Clinical Trial Results in HIV-1 Treatment-Naïve Adolescent Subjects Aged 12 to Less than 18

16 HOW SUPPLIED/STORAGE AND HANDLING

17 PATIENT COUNSELING INFORMATION

* Sections or subsections omitted from the full prescribing information are not listed. 


\section{FULL PRESCRIBING INFORMATION}

\section{WARNING: LACTIC ACIDOSIS/SEVERE HEPATOMEGALY WITH STEATOSIS and POST TREATMENT ACUTE EXACERBATION OF HEPATITIS B}

Lactic acidosis and severe hepatomegaly with steatosis, including fatal cases, have been reported with the use of nucleoside analogs in combination with other antiretrovirals [see Warnings and Precautions (5.1)].

GENVOYA is not approved for the treatment of chronic hepatitis B virus (HBV) infection and the safety and efficacy of GENVOYA have not been established in patients coinfected with human immunodeficiency virus-1 (HIV-1) and HBV. Severe acute exacerbations of hepatitis $B$ have been reported in patients who are coinfected with HIV-1 and HBV and have discontinued products containing emtricitabine and/or tenofovir disoproxil fumarate (TDF), and may occur with discontinuation of GENVOYA. Hepatic function should be monitored closely with both clinical and laboratory follow-up for at least several months in patients who are coinfected with HIV-1 and HBV and discontinue GENVOYA. If appropriate, initiation of anti-hepatitis $B$ therapy may be warranted [see Warnings and Precautions (5.2)].

\section{INDICATIONS AND USAGE}

GENVOYA is indicated as a complete regimen for the treatment of HIV-1 infection in adults and pediatric patients 12 years of age and older weighing at least $35 \mathrm{~kg}$ who have no antiretroviral treatment history or to replace the current antiretroviral regimen in those who are virologically-suppressed (HIV-1 RNA less than 50 copies per $\mathrm{mL}$ ) on a stable antiretroviral regimen for at least 6 months with no history of treatment failure and no known substitutions associated with resistance to the individual components of GENVOYA [see Clinical Studies (14)].

\section{DOSAGE AND ADMINISTRATION}

\subsection{Testing Prior to Initiation and During Treatment with GENVOYA}

Prior to initiation of GENVOYA, patients should be tested for hepatitis B virus infection [see Warnings and Precautions (5.2)].

It is recommended that serum creatinine, serum phosphorous, estimated creatinine clearance, urine glucose and urine protein should be assessed before initiating GENVOYA and during therapy in all patients as clinically appropriate [see Warnings and Precautions (5.6)].

\subsection{Recommended Dosage}

GENVOYA is a four-drug fixed dose combination product containing $150 \mathrm{mg}$ of elvitegravir, $150 \mathrm{mg}$ of cobicistat, $200 \mathrm{mg}$ of emtricitabine, and $10 \mathrm{mg}$ of tenofovir 
alafenamide (TAF). The recommended dosage of GENVOYA is one tablet taken orally once daily with food in adults and pediatric patients 12 years of age and older with body weight at least $35 \mathrm{~kg}$ and creatinine clearance greater than or equal to $30 \mathrm{~mL}$ per minute [see Use in Specific Populations (8.6) and Clinical Pharmacology (12.3)].

\subsection{Not Recommended in Patients with Severe Renal Impairment}

GENVOYA is not recommended in patients with estimated creatinine clearance below $30 \mathrm{~mL}$ per minute [see Use in Specific Populations (8.6)].

\subsection{Not Recommended in Patients with Severe Hepatic Impairment}

GENVOYA is not recommended in patients with severe hepatic impairment (Child-Pugh Class C) [see Use in Specific Populations (8.7) and Clinical Pharmacology (12.3)].

\section{DOSAGE FORMS AND STRENGTHS}

Each GENVOYA tablet contains $150 \mathrm{mg}$ of elvitegravir, $150 \mathrm{mg}$ of cobicistat, $200 \mathrm{mg}$ of emtricitabine, and $10 \mathrm{mg}$ of tenofovir alafenamide (TAF) (equivalent to $11.2 \mathrm{mg}$ of tenofovir alafenamide fumarate).

The tablets are green, capsule-shaped, film-coated tablets, debossed with "GSI" on one side of the tablet and the number " 510 " on the other side of the tablet.

\section{CONTRAINDICATIONS}

Coadministration of GENVOYA is contraindicated with drugs that are highly dependent on CYP3A for clearance and for which elevated plasma concentrations are associated with serious and/or life-threatening events. These drugs and other contraindicated drugs (which may lead to reduced efficacy of GENVOYA and possible resistance) are listed in Table 1 [see Drug Interactions (7.5) and Clinical Pharmacology (12.3)]. 
Table 1 Drugs that are Contraindicated with GENVOYA

\begin{tabular}{|c|c|c|}
\hline Drug Class & $\begin{array}{l}\text { Drugs within Class } \\
\text { that are } \\
\text { Contraindicated } \\
\text { with GENVOYA }\end{array}$ & Clinical Comment \\
\hline $\begin{array}{l}\text { Alpha 1-Adrenoreceptor } \\
\text { Antagonist }\end{array}$ & Alfuzosin & $\begin{array}{l}\text { Potential for increased alfuzosin concentrations, } \\
\text { which can result in hypotension. }\end{array}$ \\
\hline Anticonvulsants & $\begin{array}{l}\text { Carbamazepine* } \\
\text { Phenobarbital } \\
\text { Phenytoin }\end{array}$ & $\begin{array}{l}\text { Carbamazepine, phenobarbital, and phenytoin are } \\
\text { potent inducers of CYP } 450 \text { metabolism and may } \\
\text { cause significant decrease in the plasma } \\
\text { concentration of elvitegravir, cobicistat, and TAF. This } \\
\text { may result in loss of therapeutic effect to GENVOYA. }\end{array}$ \\
\hline Antimycobacterial & Rifampin & $\begin{array}{l}\text { Rifampin is a potent inducer of CYP450 metabolism } \\
\text { and may cause significant decrease in the plasma } \\
\text { concentration of elvitegravir, cobicistat, and TAF. This } \\
\text { may result in loss of therapeutic effect to GENVOYA. }\end{array}$ \\
\hline Antipsychotics & $\begin{array}{l}\text { Lurasidone } \\
\text { Pimozide }\end{array}$ & $\begin{array}{l}\text { Potential for serious and/or life-threatening reactions. } \\
\text { Potential for serious and/or life-threatening reactions } \\
\text { such as cardiac arrhythmias. }\end{array}$ \\
\hline Ergot Derivatives & $\begin{array}{l}\text { Dihydroergotamine } \\
\text { Ergotamine } \\
\text { Methylergonovine }\end{array}$ & $\begin{array}{l}\text { Potential for serious and/or life-threatening events } \\
\text { such as acute ergot toxicity characterized by } \\
\text { peripheral vasospasm and ischemia of the } \\
\text { extremities and other tissues. }\end{array}$ \\
\hline GI Motility Agent & Cisapride & $\begin{array}{l}\text { Potential for serious and/or life-threatening events } \\
\text { such as cardiac arrhythmias. }\end{array}$ \\
\hline Herbal Products & $\begin{array}{l}\text { St. John's wort } \\
\text { (Hypericum } \\
\text { perforatum) }\end{array}$ & $\begin{array}{l}\text { Coadministration of products containing St. John's } \\
\text { wort and GENVOYA may result in reduced plasma } \\
\text { concentrations of elvitegravir, cobicistat, and TAF. } \\
\text { This may result in loss of therapeutic effect and } \\
\text { development of resistance. }\end{array}$ \\
\hline $\begin{array}{l}\text { HMG-CoA Reductase } \\
\text { Inhibitors }\end{array}$ & $\begin{array}{l}\text { Lovastatin } \\
\text { Simvastatin }\end{array}$ & $\begin{array}{l}\text { Potential for serious reactions such as myopathy, } \\
\text { including rhabdomyolysis. }\end{array}$ \\
\hline $\begin{array}{l}\text { Phosphodiesterase-5 } \\
\text { (PDE5) Inhibitor }\end{array}$ & $\begin{array}{l}\text { Sildenafil }^{a} \text { when } \\
\text { dosed as REVATIO } \\
\text { for the treatment of } \\
\text { pulmonary arterial } \\
\text { hypertension }\end{array}$ & $\begin{array}{l}\text { There is increased potential for sildenafil-associated } \\
\text { adverse events (which include visual disturbances, } \\
\text { hypotension, priapism, and syncope). }\end{array}$ \\
\hline Sedative/hypnotics & $\begin{array}{l}\text { Triazolam } \\
\text { Orally administered } \\
\text { midazolam }\end{array}$ & $\begin{array}{l}\text { Triazolam and orally administered midazolam are } \\
\text { extensively metabolized by CYP3A4. } \\
\text { Coadministration of triazolam or orally administered } \\
\text { midazolam with GENVOYA may cause large } \\
\text { increases in the concentration of these } \\
\text { benzodiazepines. The potential exists for serious } \\
\text { and/or life threatening events such as prolonged or } \\
\text { increased sedation or respiratory depression. }\end{array}$ \\
\hline
\end{tabular}

* Indicates that a drug-drug interaction trial was conducted.

a. See Drug Interactions (7), Table 5 for sildenafil when used for erectile dysfunction. 
b. See Drug Interactions (7), Table 5 for parenterally administered midazolam.

\section{$5 \quad$ WARNINGS AND PRECAUTIONS}

\subsection{Lactic Acidosis/Severe Hepatomegaly with Steatosis}

Lactic acidosis and severe hepatomegaly with steatosis, including fatal cases, have been reported with the use of nucleoside analogs in combination with other antiretrovirals. A majority of these cases have been in women. Obesity and prolonged nucleoside exposure may be risk factors. Particular caution should be exercised when administering nucleoside analogs to any patient with known risk factors for liver disease; however, cases have also been reported in patients with no known risk factors. Since TAF and emtricitabine are nucleos(t)ide analogs, treatment with GENVOYA should be suspended in any patient who develops clinical or laboratory findings suggestive of lactic acidosis or pronounced hepatotoxicity (which may include hepatomegaly and steatosis even in the absence of marked transaminase elevations).

\subsection{Severe Acute Exacerbation of Hepatitis B in Patients Coinfected with HIV-1 and HBV}

Patients with HIV-1 should be tested for the presence of hepatitis B virus (HBV) before initiating antiretroviral therapy [see Dosage and Administration (2.1)]. GENVOYA is not approved for the treatment of chronic HBV infection and the safety and efficacy of GENVOYA have not been established in patients coinfected with HIV-1 and HBV.

Severe acute exacerbations of hepatitis B (e.g., liver decompensation and liver failure) have been reported in patients who are coinfected with HIV-1 and HBV and have discontinued products containing emtricitabine and/or tenofovir disoproxil fumarate (TDF), and may occur with discontinuation of GENVOYA. Patients coinfected with HIV-1 and HBV who discontinue GENVOYA should be closely monitored with both clinical and laboratory follow-up for at least several months after stopping treatment. If appropriate, initiation of anti-hepatitis B therapy may be warranted, especially in patients with advanced liver disease or cirrhosis, since post-treatment exacerbation of hepatitis may lead to hepatic decompensation and liver failure.

\subsection{Risk of Adverse Reactions or Loss of Virologic Response Due to Drug Interactions}

The concomitant use of GENVOYA and other drugs may result in known or potentially significant drug interactions, some of which may lead to [see Contraindications (4) and Drug Interactions (7.5)]:

- Loss of therapeutic effect of GENVOYA and possible development of resistance.

- Possible clinically significant adverse reactions from greater exposures of concomitant drugs.

See Table 5 for steps to prevent or manage these possible and known significant drug interactions, including dosing recommendations. Consider the potential for drug 
interactions prior to and during GENVOYA therapy; review concomitant medications during GENVOYA therapy; and monitor for the adverse reactions associated with the concomitant drugs.

\subsection{Fat Redistribution}

Redistribution or accumulation of body fat including central obesity, dorsocervical fat enlargement (buffalo hump), peripheral wasting, facial wasting, breast enlargement, and "cushingoid appearance" have been observed in patients receiving antiretroviral therapy. The mechanism and long-term consequences of these events are currently unknown. A causal relationship has not been established.

\subsection{Immune Reconstitution Syndrome}

Immune reconstitution syndrome has been reported in patients treated with combination antiretroviral therapy, including emtricitabine, a component of GENVOYA. During the initial phase of combination antiretroviral treatment, patients whose immune system responds may develop an inflammatory response to indolent or residual opportunistic infections [such as Mycobacterium avium infection, cytomegalovirus, Pneumocystis jirovecii pneumonia (PCP), or tuberculosis], which may necessitate further evaluation and treatment.

Autoimmune disorders (such as Graves' disease, polymyositis, and Guillain-Barré syndrome) have also been reported to occur in the setting of immune reconstitution, however, the time to onset is more variable, and can occur many months after initiation of treatment.

\subsection{New Onset or Worsening Renal Impairment}

Renal impairment, including cases of acute renal failure and Fanconi syndrome (renal tubular injury with severe hypophosphatemia), has been reported with the use of tenofovir prodrugs in both animal toxicology studies and human trials. In clinical trials of GENVOYA, there have been no cases of Fanconi syndrome or Proximal Renal Tubulopathy (PRT). In clinical trials of GENVOYA in treatment-naïve subjects and in virologically suppressed subjects switched to GENVOYA with eGFRs greater than 50 $\mathrm{mL}$ per minute, renal serious adverse events or discontinuations due to renal adverse reactions were encountered in less than $1 \%$ of participants treated with GENVOYA. In a study of virologically suppressed subjects with baseline eGFRs between 30 and $69 \mathrm{~mL}$ per minute treated with GENVOYA for a median duration of 108 weeks, GENVOYA was permanently discontinued due to worsening renal function in three of $80(4 \%)$ subjects with a baseline eGFR between 30 and $50 \mathrm{~mL}$ per minute and two of $162(1 \%)$ with a baseline eGFR greater than or equal to $50 \mathrm{~mL}$ per minute [see Adverse Reactions (6.1)]. GENVOYA is not recommended in patients with estimated creatinine clearance below $30 \mathrm{~mL}$ per minute.

Patients taking tenofovir prodrugs who have impaired renal function and those taking nephrotoxic agents including non-steroidal anti-inflammatory drugs are at increased risk of developing renal-related adverse reactions. 
It is recommended that serum creatinine, serum phosphorous, estimated creatinine clearance, urine glucose and urine protein be assessed before initiating GENVOYA and during therapy in all patients as clinically appropriate. Discontinue GENVOYA in patients who develop clinically significant decreases in renal function or evidence of Fanconi syndrome.

Cobicistat, a component of GENVOYA, produces elevations of serum creatinine due to inhibition of tubular secretion of creatinine without affecting glomerular filtration [see Adverse Reactions (6.1)]. The elevation is typically seen within 2 weeks of starting therapy and is reversible after discontinuation. Patients who experience a confirmed increase in serum creatinine of greater than $0.4 \mathrm{mg}$ per $\mathrm{dL}$ from baseline should be closely monitored for renal safety.

\section{ADVERSE REACTIONS}

The following adverse drug reactions are discussed in other sections of the labeling:

- Lactic Acidosis/Severe Hepatomegaly with Steatosis [see Boxed Warning and Warnings and Precautions (5.1)]

- Severe Acute Exacerbations of Hepatitis B [see Boxed Warning and Warnings and Precautions (5.2)]

- Immune Reconstitution Syndrome [see Warnings and Precautions (5.5)]

- New Onset or Worsening Renal Impairment [see Warnings and Precautions (5.6)]

\subsection{Clinical Trials Experience}

Because clinical trials are conducted under widely varying conditions, adverse reaction rates observed in the clinical trials of a drug cannot be directly compared to rates in the clinical trials of another drug and may not reflect the rates observed in practice.

\section{Clinical Trials in Treatment-Naïve Adults}

The primary safety assessment of GENVOYA was based on Week 96 pooled data from 1733 subjects in two randomized, double-blind, active-controlled trials, Study 104 and Study 111, in antiretroviral treatment-naïve HIV-1 infected adult subjects. A total of 866 subjects received one tablet of GENVOYA once daily [see Clinical Studies (14.2)].

The most common adverse reaction (all Grades) reported in at least $10 \%$ of subjects in the GENVOYA group was nausea. The proportion of subjects who discontinued treatment with GENVOYA or STRIBILD ${ }^{\circledR}$ due to adverse events, regardless of severity, was $1 \%$ and $2 \%$, respectively. Table 2 displays the frequency of adverse reactions (all Grades) greater than or equal to $5 \%$ in the GENVOYA group. 
Table 2 Adverse Reactions ${ }^{a}$ (All Grades) Reported in $\geq 5 \%$ of HIV-1 Infected Treatment-Naïve Adults Receiving GENVOYA in Studies 104 and 111 (Week 96 analysis)

\begin{tabular}{|c|c|c|}
\hline $\begin{array}{c}\text { GASTROINTESTINAL DISORDERS } \\
\text { Diarrhea } \\
\text { Nausea }\end{array}$ & $\begin{array}{c}\text { GENVOYA } \\
\mathrm{N}=866\end{array}$ & $\begin{array}{c}\text { STRIBILD } \\
\mathrm{N}=867\end{array}$ \\
\hline $\begin{array}{c}\text { GENERAL DISORDERS AND ADMINISTRATION } \\
\text { SITE CONDITIONS } \\
\text { Fatigue }\end{array}$ & $7 \%$ & $9 \%$ \\
\hline $\begin{array}{c}\text { NERVOUS SYSTEM DISORDERS } \\
\text { Headache }\end{array}$ & $5 \%$ & $13 \%$ \\
\hline
\end{tabular}

a. Frequencies of adverse reactions are based on all adverse events attributed to study drugs by the investigator.

The majority of events presented in Table 2 occurred at severity Grade 1.

Clinical Trials in Virologically Suppressed Adults

The safety of GENVOYA in virologically-suppressed adults was based on Week 48 data from 959 subjects in a randomized, open-label, active-controlled trial (Study 109) in which virologically-suppressed subjects were switched from a TDF-containing combination regimen to GENVOYA. Overall, the safety profile of GENVOYA in subjects in this study was similar to that of treatment-naïve subjects [see Clinical Studies (14.3)].

\section{Clinical Trials in Adult Subjects with Renal Impairment}

In an open-label trial (Study 112), $248 \mathrm{HIV}-1$ infected subjects with eGFR of 30 to $69 \mathrm{~mL}$ per minute (by Cockcroft-Gault method) were treated with GENVOYA for a median duration of 108 weeks. Of these subjects, $65 \%$ had previously been on a stable TDFcontaining regimen. A total of 5 subjects permanently discontinued GENVOYA due to the development of renal adverse events. Three of these five were among the 80 subjects with baseline eGFRs of $<50 \mathrm{~mL} / \mathrm{min}$ and two subjects were among the 162 subjects with baseline eGFRs of $\geq 50 \mathrm{~mL} / \mathrm{min}$. One additional subject with baseline eGFR of $\geq 50 \mathrm{~mL} / \mathrm{min}$ developed acute renal failure. Following a brief interruption, GENVOYA was resumed and this subject's renal function returned to baseline. Overall, renally impaired subjects receiving GENVOYA in this study had a mean serum creatinine of $1.5 \mathrm{mg} / \mathrm{dL}$ at baseline and $1.4 \mathrm{mg} / \mathrm{dL}$ at Week 96 . Otherwise, the safety profile of GENVOYA in subjects in this study was similar to that of subjects with normal renal function [see Clinical Studies (14.4)]. 


\section{Renal Laboratory Tests and Renal Safety}

Treatment-Naïve Adults:

Cobicistat (a component of GENVOYA) has been shown to increase serum creatinine due to inhibition of tubular secretion of creatinine without affecting glomerular filtration [see Clinical Pharmacology (12.2)]. Increases in serum creatinine occurred by Week 2 of treatment and remained stable through 96 weeks.

In two 96-week randomized, controlled trials in a total of 1733 treatment-naïve adults with a median baseline eGFR of $115 \mathrm{~mL}$ per minute, mean serum creatinine increased by less than $0.1 \mathrm{mg}$ per $\mathrm{dL}$ in the GENVOYA group and by $0.1 \mathrm{mg}$ per $\mathrm{dL}$ in the STRIBILD group from baseline to Week 96.

\section{Virologically Suppressed Adults:}

In a study of 1436 virologically-suppressed TDF-treated adults with a mean baseline eGFR of $112 \mathrm{~mL}$ per minute who were randomized to continue their treatment regimen or switch to GENVOYA, at Week 48 mean serum creatinine was similar to baseline for both those continuing baseline treatment and those switching to GENVOYA.

\section{Bone Mineral Density Effects}

Treatment-Naïve Adults:

In the pooled analysis of Studies 104 and 111, bone mineral density (BMD) from baseline to Week 96 was assessed by dual-energy X-ray absorptiometry (DXA) to compare the bone safety of TAF to that of TDF when administered as GENVOYA or STRIBILD, respectively. Mean BMD decreased from baseline to Week 96 by $-0.96 \%$ with GENVOYA compared to $-2.79 \%$ with STRIBILD at the lumbar spine and $-0.67 \%$ compared to $-3.28 \%$ at the total hip. BMD declines of $5 \%$ or greater at the lumbar spine were experienced by $12 \%$ of GENVOYA subjects and $26 \%$ of STRIBILD subjects. BMD declines of $7 \%$ or greater at the femoral neck were experienced by $11 \%$ of GENVOYA subjects and $26 \%$ of STRIBILD subjects. The long-term clinical significance of these BMD changes is not known.

\section{Virologically Suppressed Adults:}

In Study 109, TDF-treated subjects were randomized to continue their TDF-based regimen or switch to GENVOYA; changes in BMD from baseline to Week 48 were assessed by DXA. Mean BMD increased in subjects who switched to GENVOYA (1.86\% lumbar spine, $1.95 \%$ total hip) and decreased slightly in subjects who continued their baseline regimen $(-0.11 \%$ lumbar spine, $-0.14 \%$ total hip). BMD declines of $5 \%$ or greater at the lumbar spine were experienced by $1 \%$ of GENVOYA subjects and $6 \%$ of subjects who continued their TDF-based regimen. BMD declines of $7 \%$ or greater at the femoral neck were experienced by $1 \%$ of GENVOYA subjects and $4 \%$ of subjects who continued their TDF-based regimen. The long-term clinical significance of these BMD changes is not known. 


\section{Laboratory Abnormalities:}

The frequency of laboratory abnormalities (Grades 3-4) occurring in at least $2 \%$ of subjects receiving GENVOYA in Studies 104 and 111 are presented in Table 3.

Table 3 Laboratory Abnormalities (Grades 3-4) Reported in $\geq 2 \%$ of Subjects Receiving GENVOYA in Studies 104 and 111 (Week 96 analysis)

\begin{tabular}{|c|c|c|}
\hline Laboratory Parameter Abnormality ${ }^{a}$ & $\begin{array}{c}\text { GENVOYA } \\
\mathrm{N}=866\end{array}$ & $\begin{array}{c}\text { STRIBILD } \\
\mathrm{N}=867\end{array}$ \\
\hline Amylase & $2 \%$ & $4 \%$ \\
\hline AST & $2 \%$ & $2 \%$ \\
\hline Creatine Kinase $(\geq 10.0 \times$ ULN) & $9 \%$ & $7 \%$ \\
\hline Urine RBC (Hematuria) (>75 RBC/HPF) & $3 \%$ & $3 \%$ \\
\hline LDL-cholesterol (fasted) (>190 mg/dL) & $8 \%$ & $4 \%$ \\
\hline Total cholesterol (fasted) (>300mg/dL) & $3 \%$ & $2 \%$ \\
\hline
\end{tabular}

a. Frequencies are based on treatment-emergent laboratory abnormalities.

Serum Lipids:

Subjects receiving GENVOYA experienced greater increases in serum lipids compared to those receiving STRIBILD.

Changes from baseline in total cholesterol, HDL-cholesterol, LDL-cholesterol, triglycerides and total cholesterol to HDL ratio are presented in Table 4. 
Table 4 Lipid Values, Mean Change from Baseline, Reported in Subjects Receiving GENVOYA or STRIBILD in Studies 104 and $111^{\mathrm{a}}$

\begin{tabular}{|c|c|c|c|c|}
\hline & \multicolumn{2}{|c|}{$\begin{array}{l}\text { GENVOYA } \\
\qquad=866\end{array}$} & \multicolumn{2}{|c|}{$\begin{array}{l}\text { STRIBILD } \\
\mathrm{N}=867\end{array}$} \\
\hline & Baseline & Week 96 & Baseline & Week 96 \\
\hline & $\mathrm{mg} / \mathrm{dL}$ & Change $^{b}$ & $\mathrm{mg} / \mathrm{dL}$ & Change $^{b}$ \\
\hline $\begin{array}{l}\text { Total Cholesterol } \\
\text { (fasted) }\end{array}$ & $\begin{array}{c}162 \\
{[N=692]}\end{array}$ & $\begin{array}{c}+31 \\
{[N=692]}\end{array}$ & $\begin{array}{c}166 \\
{[N=679]}\end{array}$ & $\begin{array}{c}+15 \\
{[N=679]}\end{array}$ \\
\hline $\begin{array}{l}\text { HDL-cholesterol } \\
\text { (fasted) }\end{array}$ & $\begin{array}{c}46 \\
{[N=692]}\end{array}$ & $\begin{array}{c}+7 \\
{[N=692]}\end{array}$ & $\begin{array}{c}46 \\
{[N=679]}\end{array}$ & $\begin{array}{c}+4 \\
{[N=679]}\end{array}$ \\
\hline $\begin{array}{l}\text { LDL-cholesterol } \\
\text { (fasted) }\end{array}$ & $\begin{array}{c}103 \\
{[N=688]}\end{array}$ & $\begin{array}{c}+18 \\
{[\mathrm{~N}=688]}\end{array}$ & $\begin{array}{c}107 \\
{[\mathrm{~N}=680]}\end{array}$ & $\begin{array}{c}+7 \\
{[N=680]}\end{array}$ \\
\hline $\begin{array}{l}\text { Triglycerides } \\
\text { (fasted) }\end{array}$ & $\begin{array}{c}113 \\
{[N=692]}\end{array}$ & $\begin{array}{c}+31 \\
{[N=692]}\end{array}$ & $\begin{array}{c}115 \\
{[N=679]}\end{array}$ & $\begin{array}{c}+13 \\
{[N=679]}\end{array}$ \\
\hline $\begin{array}{l}\text { Total Cholesterol } \\
\text { to HDL ratio }\end{array}$ & $\begin{array}{c}3.7 \\
{[\mathrm{~N}=692]}\end{array}$ & $\begin{array}{c}0.2 \\
{[\mathrm{~N}=692]}\end{array}$ & $\begin{array}{c}3.8 \\
{[N=679]}\end{array}$ & $\begin{array}{c}0 \\
{[N=679]}\end{array}$ \\
\hline
\end{tabular}

a. Excludes subjects who received lipid lowering agents during the treatment period.

b. The change from baseline is the mean of within-subject changes from baseline for subjects with both baseline and Week 96 values.

\section{Clinical Trials in Pediatric Subjects:}

The safety of GENVOYA in HIV-1 infected, treatment-naïve pediatric subjects aged 12 to less than 18 years and weighing at least $35 \mathrm{~kg}(77 \mathrm{lbs})$ was evaluated through 24 weeks in an open-label clinical trial (Study 106) [see Clinical Studies (14.5)]. The safety profile in 23 adolescent subjects who received treatment with GENVOYA was similar to that in adults. One 13 year old female subject developed unexplained uveitis while receiving GENVOYA that resolved and did not require discontinuation of GENVOYA.

Among the 23 pediatric subjects receiving GENVOYA for 24 weeks, mean BMD increased from baseline to Week $24,+1.7 \%$ at the lumbar spine and $+0.8 \%$ for the total body less head. Mean changes from baseline BMD Z-scores were -0.10 for lumbar spine and -0.11 for total body less head at Week 24 . Two GENVOYA subjects had significant (greater than 4\%) lumbar spine BMD loss at Week 24.

\section{DRUG INTERACTIONS}

\subsection{Not Recommended with Other Antiretroviral Medications}

GENVOYA is a complete regimen for the treatment of HIV-1 infection; therefore, coadministration of GENVOYA with other antiretroviral medications for treatment of HIV1 infection should be avoided. Complete information regarding potential drug-drug interactions with other antiretroviral medications is not provided [see Contraindications, Warnings and Precautions (5.3) and Clinical Pharmacology (12.3)]. 


\subsection{Potential for GENVOYA to Affect Other Drugs}

Cobicistat, a component of GENVOYA, is an inhibitor of CYP3A and CYP2D6 and an inhibitor of the following transporters: p-glycoprotein (P-gp), BCRP, OATP1B1 and OATP1B3. Thus, coadministration of GENVOYA with drugs that are primarily metabolized by CYP3A or CYP2D6, or are substrates of P-gp, BCRP, OATP1B1 or OATP1B3 may result in increased plasma concentrations of such drugs (see Table 5). Elvitegravir is a modest inducer of CYP2C9 and may decrease the plasma concentrations of CYP2C9 substrates. TAF is not an inhibitor of CYP1A2, CYP2B6, CYP2C8, CYP2C9, CYP2C19, CYP2D6, or UGT1A1. TAF is a weak inhibitor of CYP3A in vitro. TAF is not an inhibitor or inducer of CYP3A in vivo.

\subsection{Potential for Other Drugs to Affect One or More Components of GENVOYA}

Elvitegravir and cobicistat, components of GENVOYA, are metabolized by CYP3A. Cobicistat is also metabolized, to a minor extent, by CYP2D6.

Drugs that induce CYP3A activity are expected to increase the clearance of elvitegravir and cobicistat, resulting in decreased plasma concentration of cobicistat, elvitegravir, and TAF, which may lead to loss of therapeutic effect of GENVOYA and development of resistance (see Table 5).

Coadministration of GENVOYA with other drugs that inhibit CYP3A may decrease the clearance and increase the plasma concentration of cobicistat (see Table 5).

TAF, a component of GENVOYA, is a substrate of P-gp, BCRP, OATP1B1 and OATP1B3. Drugs that inhibit P-gp and/or BCRP, such as cobicistat, may increase the absorption of TAF (see Table 10). However, when TAF is administered as a component of GENVOYA, its availability is increased by cobicistat and a further increase of TAF concentrations is not expected upon coadministration of an additional P-gp and/or BCRP inhibitor. Drugs that induce P-gp activity are expected to decrease the absorption of TAF, resulting in decreased plasma concentration of TAF.

\subsection{Drugs Affecting Renal Function}

Because emtricitabine and tenofovir are primarily excreted by the kidneys by a combination of glomerular filtration and active tubular secretion, coadministration of GENVOYA with drugs that reduce renal function or compete for active tubular secretion may increase concentrations of emtricitabine, tenofovir, and other renally eliminated drugs and this may increase the risk of adverse reactions. Some examples of drugs that are eliminated by active tubular secretion include, but are not limited to, acyclovir, cidofovir, ganciclovir, valacyclovir, valganciclovir, aminoglycosides (e.g., gentamicin), and high-dose or multiple NSAIDs [see Warnings and Precautions (5.6)].

\subsection{Established and Other Potentially Significant Interactions}

Table 5 provides a listing of established or potentially clinically significant drug interactions. The drug interactions described are based on studies conducted with either 
GENVOYA, the components of GENVOYA (elvitegravir, cobicistat, emtricitabine, and tenofovir alafenamide) as individual agents and/or in combination, or are predicted drug interactions that may occur with GENVOYA [for magnitude of interaction, see Clinical Pharmacology (12.3)]. The table includes potentially significant interactions but is not all inclusive.

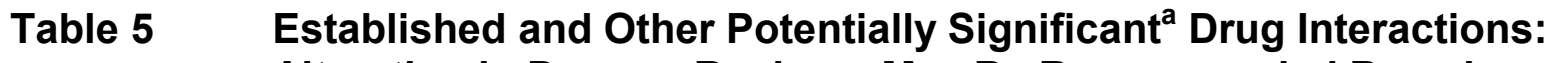
Alteration in Dose or Regimen May Be Recommended Based on Drug Interaction Studies or Predicted Interaction

\begin{tabular}{|c|c|c|}
\hline $\begin{array}{l}\text { Concomitant Drug } \\
\text { Class: Drug Name }\end{array}$ & $\begin{array}{l}\text { Effect on } \\
\text { Concentration }\end{array}$ & Clinical Comment \\
\hline $\begin{array}{l}\text { Acid Reducing } \\
\text { Agents: } \\
\text { antacids* } \\
\text { e.g., } \\
\text { aluminum and } \\
\text { magnesium } \\
\text { hydroxide }\end{array}$ & $\downarrow$ elvitegravir & $\begin{array}{l}\text { Separate GENVOYA and antacid administration by at } \\
\text { least } 2 \text { hours. }\end{array}$ \\
\hline $\begin{array}{l}\text { Antiarrhythmics: } \\
\text { e.g., } \\
\text { amiodarone } \\
\text { bepridil } \\
\text { digoxin* }^{*} \\
\text { disopyramide } \\
\text { flecainide } \\
\text { systemic lidocaine } \\
\text { mexiletine } \\
\text { propafenone } \\
\text { quinidine }\end{array}$ & $\begin{array}{l}\uparrow \text { antiarrhythmics } \\
\uparrow \text { digoxin }\end{array}$ & $\begin{array}{l}\text { Caution is warranted and therapeutic concentration } \\
\text { monitoring, if available, is recommended for } \\
\text { antiarrhythmics when coadministered with GENVOYA. }\end{array}$ \\
\hline $\begin{array}{l}\text { Antibacterials: } \\
\text { clarithromycin } \\
\text { telithromycin }\end{array}$ & $\begin{array}{l}\uparrow \text { clarithromycin } \\
\uparrow \text { telithromycin } \\
\uparrow \text { cobicistat }\end{array}$ & 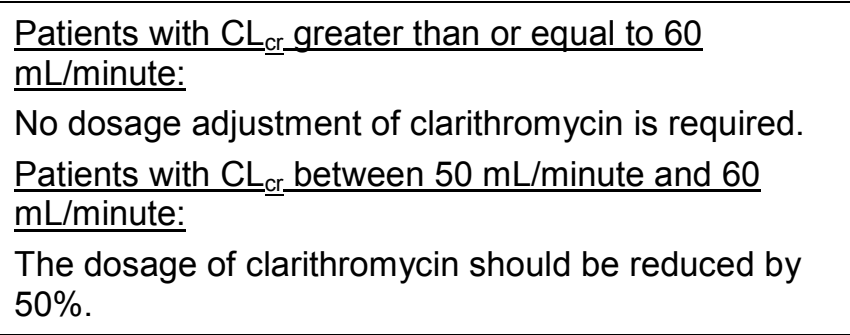 \\
\hline $\begin{array}{l}\text { Anticoagulants: } \\
\text { warfarin }\end{array}$ & $\begin{array}{l}\text { Effect on warfarin } \\
\text { unknown }\end{array}$ & $\begin{array}{l}\text { Monitor the international normalized ratio (INR) upon } \\
\text { coadministration with GENVOYA. }\end{array}$ \\
\hline $\begin{array}{l}\text { Anticonvulsants: } \\
\text { ethosuximide } \\
\text { oxcarbazepine }\end{array}$ & $\begin{array}{l}\uparrow \text { ethosuximide } \\
\downarrow \text { elvitegravir } \\
\downarrow \text { cobicistat } \\
\downarrow \text { TAF }\end{array}$ & $\begin{array}{l}\text { Contraindicated anticonvulsants [see } \\
\text { Contraindications (4)] } \\
\text { Alternative anticonvulsants should be considered } \\
\text { when GENVOYA is administered with oxcarbazepine. } \\
\text { Clinical monitoring is recommended upon } \\
\text { coadministration of ethosuximide with GENVOYA. }\end{array}$ \\
\hline
\end{tabular}




\begin{tabular}{|c|c|c|}
\hline $\begin{array}{l}\text { Antidepressants: } \\
\text { Selective Serotonin } \\
\text { Reuptake Inhibitors } \\
\text { (SSRIs) } \\
\text { e.g., } \\
\text { paroxetine } \\
\text { Tricyclic } \\
\text { Antidepressants } \\
\text { (TCAs) } \\
\text { e.g., } \\
\text { amitriptyline } \\
\text { desipramine* } \\
\text { imipramine } \\
\text { nortriptyline } \\
\text { bupropion } \\
\text { trazodone }\end{array}$ & $\begin{array}{l}\uparrow \text { SSRIs (except } \\
\text { sertraline) } \\
\uparrow \text { TCAs } \\
\uparrow \text { trazodone }\end{array}$ & $\begin{array}{l}\text { Careful dosage titration of the antidepressant and } \\
\text { monitoring for antidepressant response are } \\
\text { recommended when coadministered with GENVOYA. }\end{array}$ \\
\hline $\begin{array}{l}\text { Antifungals: } \\
\text { itraconazole } \\
\text { ketoconazole* } \\
\text { voriconazole }\end{array}$ & $\begin{array}{l}\uparrow \text { elvitegravir } \\
\uparrow \text { cobicistat } \\
\uparrow \text { itraconazole } \\
\uparrow \text { ketoconazole } \\
\uparrow \text { voriconazole }\end{array}$ & $\begin{array}{l}\text { When administering with GENVOYA, the maximum } \\
\text { daily dosage of ketoconazole or itraconazole should } \\
\text { not exceed } 200 \mathrm{mg} \text { per day. } \\
\text { An assessment of benefit/risk ratio is recommended to } \\
\text { justify use of voriconazole with GENVOYA. }\end{array}$ \\
\hline $\begin{array}{l}\text { Anti-gout: } \\
\text { colchicine }\end{array}$ & $\uparrow$ colchicine & $\begin{array}{l}\text { GENVOYA is not recommended to be coadministered } \\
\text { with colchicine to patients with renal or hepatic } \\
\text { impairment. } \\
\text { Treatment of gout-flares - coadministration of } \\
\text { colchicine in patients receiving GENVOYA: } \\
0.6 \mathrm{mg} \text { ( } 1 \text { tablet) } x 1 \text { dose, followed by } 0.3 \mathrm{mg} \text { (half } \\
\text { tablet) } 1 \text { hour later. Treatment course to be repeated } \\
\text { no earlier than } 3 \text { days. } \\
\text { Prophylaxis of gout-flares - coadministration of } \\
\text { colchicine in patients receiving GENVOYA: } \\
\text { If the original regimen was } 0.6 \mathrm{mg} \text { twice a day, the } \\
\text { regimen should be adjusted to } 0.3 \mathrm{mg} \text { once a day. If } \\
\text { the original regimen was } 0.6 \mathrm{mg} \text { once a day, the } \\
\text { regimen should be adjusted to } 0.3 \text { mg once every } \\
\text { other day. } \\
\text { Treatment of familial Mediterranean fever - } \\
\text { coadministration of colchicine in patients receiving } \\
\text { GENVOYA: } \\
\text { Maximum daily dosage of } 0.6 \text { mg (may be given as } 0.3 \\
\text { mg twice a day). }\end{array}$ \\
\hline $\begin{array}{l}\text { Antimycobacterial: } \\
\text { rifabutin* } \\
\text { rifapentine }\end{array}$ & $\begin{array}{l}\downarrow \text { elvitegravir } \\
\downarrow \text { cobicistat } \\
\downarrow \text { TAF }\end{array}$ & $\begin{array}{l}\text { For contraindicated antimycobacterials, [see } \\
\text { Contraindications (4)] } \\
\text { Coadministration of GENVOYA with rifabutin or }\end{array}$ \\
\hline
\end{tabular}




\begin{tabular}{|c|c|c|}
\hline & & rifapentine is not recommended. \\
\hline $\begin{array}{l}\text { Antipsychotics: } \\
\text { e.g., } \\
\text { perphenazine } \\
\text { risperidone } \\
\text { thioridazine } \\
\text { quetiapine }\end{array}$ & $\uparrow$ antipsychotic & $\begin{array}{l}\text { For contraindicated antipsychotics, [see } \\
\text { Contraindications (4)] } \\
\text { A decrease in dose of the antipsychotics that are } \\
\text { metabolized by CYP3A or CYP2D6 may be needed } \\
\text { when co-administered with GENVOYA. } \\
\text { Initiation of GENVOYA in patients taking quetiapine: } \\
\text { Consider alternative antiretroviral therapy to avoid } \\
\text { increases in quetiapine exposure. If coadministration is } \\
\text { necessary, reduce the quetiapine dose to } 1 / 6 \text { of the } \\
\text { current dose and monitor for quetiapine-associated } \\
\text { adverse reactions. Refer to the quetiapine prescribing } \\
\text { information for recommendations on adverse reaction } \\
\text { monitoring. } \\
\text { Initiation of quetiapine in patients taking GENVOYA: } \\
\text { Refer to the quetiapine prescribing information for } \\
\text { initial dosing and titration of quetiapine. }\end{array}$ \\
\hline $\begin{array}{l}\text { Benzodiazepines: } \\
\text { e.g., } \\
\text { Parenterally } \\
\text { administered } \\
\text { midazolam } \\
\text { clorazepate } \\
\text { diazepam } \\
\text { estazolam } \\
\text { flurazepam } \\
\text { lorazepam }\end{array}$ & $\begin{array}{l}\uparrow \text { diazepam } \\
\leftrightarrow \text { lorazepam } \\
\uparrow \text { midazolam }\end{array}$ & $\begin{array}{l}\text { Coadministration of GENVOYA with diazepam or } \\
\text { parenterally administered midazolam should be done } \\
\text { in a setting that ensures close clinical monitoring and } \\
\text { appropriate medical management in case of } \\
\text { respiratory depression and/or prolonged sedation. } \\
\text { Dosage reduction for midazolam should be } \\
\text { considered, especially if more than a single dose of } \\
\text { midazolam is administered. } \\
\text { Based on non-CYP-mediated elimination pathways for } \\
\text { lorazepam, no effect on plasma concentrations is } \\
\text { expected upon coadministration with GENVOYA. }\end{array}$ \\
\hline $\begin{array}{l}\text { Beta-Blockers: } \\
\text { e.g., } \\
\text { metoprolol } \\
\text { timolol }\end{array}$ & $\uparrow$ beta-blockers & $\begin{array}{l}\text { Clinical monitoring is recommended and a dosage } \\
\text { decrease of the beta blocker may be necessary when } \\
\text { these agents are coadministered with GENVOYA. }\end{array}$ \\
\hline $\begin{array}{l}\text { Calcium Channel } \\
\text { Blockers: } \\
\text { e.g., } \\
\text { amlodipine } \\
\text { diltiazem } \\
\text { felodipine } \\
\text { nicardipine } \\
\text { nifedipine } \\
\text { verapamil }\end{array}$ & $\begin{array}{l}\uparrow \text { calcium channel } \\
\text { blockers }\end{array}$ & $\begin{array}{l}\text { Caution is warranted and clinical monitoring is } \\
\text { recommended upon coadministration of calcium } \\
\text { channel blockers with GENVOYA. }\end{array}$ \\
\hline $\begin{array}{l}\text { Corticosteroid: } \\
\text { Systemic: } \\
\text { dexamethasone }\end{array}$ & $\begin{array}{l}\downarrow \text { elvitegravir } \\
\downarrow \text { cobicistat }\end{array}$ & $\begin{array}{l}\text { An alternative corticosteroid should be considered for } \\
\text { coadministration with GENVOYA. }\end{array}$ \\
\hline Corticosteroid: & $\uparrow$ fluticasone & Alternative corticosteroids should be considered, \\
\hline
\end{tabular}




\begin{tabular}{|c|c|c|}
\hline $\begin{array}{l}\text { Inhaled/Nasal: } \\
\text { fluticasone }\end{array}$ & & particularly for long term use. \\
\hline $\begin{array}{l}\text { Endothelin } \\
\text { Receptor } \\
\text { Antagonists: } \\
\text { bosentan }\end{array}$ & $\uparrow$ bosentan & $\begin{array}{l}\text { Coadministration of bosentan in patients on } \\
\text { GENVOYA: } \\
\text { In patients who have been receiving GENVOYA for at } \\
\text { least } 10 \text { days, start bosentan at } 62.5 \mathrm{mg} \text { once daily or } \\
\text { every other day based upon individual tolerability. } \\
\text { Coadministration of GENVOYA in patients on } \\
\text { bosentan: } \\
\text { Discontinue use of bosentan at least } 36 \text { hours prior to } \\
\text { initiation of GENVOYA. After at least } 10 \text { days following } \\
\text { the initiation of GENVOYA, resume bosentan at } 62.5 \\
\text { mg once daily or every other day based upon } \\
\text { individual tolerability. }\end{array}$ \\
\hline $\begin{array}{l}\text { HMG-CoA } \\
\text { Reductase } \\
\text { Inhibitors: } \\
\text { atorvastatin }\end{array}$ & $\uparrow$ atorvastatin & $\begin{array}{l}\text { For contraindicated HMG-CoA reductase } \\
\text { inhibitors, [see Contraindications (4)] } \\
\text { Initiate with the lowest starting dose of atorvastatin and } \\
\text { titrate carefully while monitoring for safety. }\end{array}$ \\
\hline $\begin{array}{l}\text { Hormonal } \\
\text { Contraceptives: } \\
\text { norgestimate/ethinyl } \\
\text { estradiol }\end{array}$ & $\begin{array}{l}\uparrow \text { norgestimate } \\
\downarrow \text { ethinyl estradiol }\end{array}$ & $\begin{array}{l}\text { The effects of increases in the concentration of the } \\
\text { progestational component norgestimate are not fully } \\
\text { known and can include increased risk of insulin } \\
\text { resistance, dyslipidemia, acne, and venous } \\
\text { thrombosis. The potential risks and benefits } \\
\text { associated with coadministration of } \\
\text { norgestimate/ethinyl estradiol with GENVOYA should } \\
\text { be considered, particularly in women who have risk } \\
\text { factors for these events. } \\
\text { The effect of GENVOYA on other hormonal } \\
\text { contraceptives (e.g., contraceptive patch, } \\
\text { contraceptive vaginal ring, or injectable } \\
\text { contraceptives) or oral contraceptives containing } \\
\text { progestogens other than norgestimate is not known; } \\
\text { therefore, alternative (non-hormonal) methods of } \\
\text { contraception can be considered. }\end{array}$ \\
\hline $\begin{array}{l}\text { Immuno- } \\
\text { suppressants: } \\
\text { e.g., } \\
\text { cyclosporine (CsA) } \\
\text { sirolimus } \\
\text { tacrolimus }\end{array}$ & $\begin{array}{l}\uparrow \text { immuno- } \\
\text { suppressants } \\
\uparrow \text { elvitegravir (with } \\
\text { CsA) } \\
\uparrow \text { cobicistat (with } \\
\text { CsA) }\end{array}$ & $\begin{array}{l}\text { Therapeutic monitoring of the immunosuppressive } \\
\text { agents is recommended upon coadministration with } \\
\text { GENVOYA. } \\
\text { Monitor for adverse events associated with GENVOYA } \\
\text { when coadministered with cyclosporine. }\end{array}$ \\
\hline $\begin{array}{l}\text { Narcotic } \\
\text { Analgesics: } \\
\text { buprenorphine/ } \\
\text { naloxone* }\end{array}$ & $\begin{array}{l}\uparrow \text { buprenorphine } \\
\uparrow \text { norbuprenorphine } \\
\downarrow \text { naloxone }\end{array}$ & $\begin{array}{l}\text { No dosage adjustment of buprenorphine/naloxone is } \\
\text { required upon coadministration with GENVOYA. } \\
\text { Patients should be closely monitored for sedation and } \\
\text { cognitive effects. }\end{array}$ \\
\hline $\begin{array}{l}\text { Inhaled Beta } \\
\text { Agonist: }\end{array}$ & $\uparrow$ salmeterol & $\begin{array}{l}\text { Coadministration of salmeterol and GENVOYA is not } \\
\text { recommended. Coadministration of salmeterol with } \\
\text { GENVOYA may result in increased risk of }\end{array}$ \\
\hline
\end{tabular}




\begin{tabular}{|c|c|c|}
\hline salmeterol & & $\begin{array}{l}\text { cardiovascular adverse events associated with } \\
\text { salmeterol, including QT prolongation, palpitations, } \\
\text { and sinus tachycardia. }\end{array}$ \\
\hline $\begin{array}{l}\text { Phosphodiesterase- } \\
5 \text { (PDE5) Inhibitors: } \\
\text { sildenafil } \\
\text { tadalafil } \\
\text { vardenafil }\end{array}$ & 个 PDE5 inhibitors & $\begin{array}{l}\text { For contraindicated PDE-5 inhibitors, [see } \\
\text { Contraindications (4)] } \\
\text { Coadministration with GENVOYA may result in an } \\
\text { increase in PDE-5 inhibitor associated adverse } \\
\text { reactions, including hypotension, syncope, visual } \\
\text { disturbances, and priapism. } \\
\text { Use of PDE-5 inhibitors for pulmonary arterial } \\
\text { hypertension (PAH): } \\
\text { Use of sildenafil is contraindicated when used for the } \\
\text { treatment of pulmonary arterial hypertension (PAH). } \\
\text { The following dose adjustments are recommended for } \\
\text { the use of tadalafil with GENVOYA: } \\
\text { Coadministration of tadalafil in patients on GENVOYA: } \\
\text { In patients receiving GENVOYA for at least } 1 \text { week, } \\
\text { start tadalafil at } 20 \text { mg once daily. Increase tadalafil } \\
\text { dose to } 40 \text { mg once daily based upon individual } \\
\text { tolerability. } \\
\text { Coadministration of GENVOYA in patients on tadalafil: } \\
\text { Avoid use of tadalafil during the initiation of } \\
\text { GENVOYA. Stop tadalafil at least } 24 \text { hours prior to } \\
\text { starting GENVOYA. After at least one week following } \\
\text { initiation of GENVOYA, resume tadalafil at } 20 \text { mg once } \\
\text { daily. Increase tadalafil dose to } 40 \text { mg once daily } \\
\text { based upon individual tolerability. } \\
\text { Use of PDE-5 inhibitors for erectile dysfunction: } \\
\text { Sildenafil at a single dose not exceeding } 25 \text { mg in } 48 \\
\text { hours, vardenafil at a single dose not exceeding } 2.5 \\
\text { mg in } 72 \text { hours, or tadalafil at a single dose not } \\
\text { exceeding } 10 \text { mg in } 72 \text { hours can be used with } \\
\text { increased monitoring for PDE-5 inhibitor associated } \\
\text { with adverse events. }\end{array}$ \\
\hline $\begin{array}{l}\text { Sedative/hypnotics: } \\
\text { buspirone } \\
\text { zolpidem }\end{array}$ & $\uparrow$ sedatives/hypnotics & $\begin{array}{l}\text { For contraindicated sedative/hypnotics, [see } \\
\text { Contraindications (4)] } \\
\text { With sedative/hypnotics, dose reduction may be } \\
\text { necessary and clinical monitoring is recommended. }\end{array}$ \\
\hline
\end{tabular}

* Indicates that a drug-drug interaction trial was conducted.

a. This table is not all inclusive.

b. $\quad \uparrow=$ Increase, $\downarrow=$ Decrease, $\leftrightarrow=$ No Effect

\subsection{Drugs without Clinically Significant Interactions with GENVOYA}

Based on drug interaction studies conducted with the components of GENVOYA, no clinically significant drug interactions have been either observed or are expected when 
GENVOYA is combined with the following drugs: entecavir, famciclovir, $\mathrm{H}_{2}$ receptor antagonists, ledipasvir, lorazepam, methadone, proton pump inhibitors, ribavirin, sertraline, sofosbuvir, and velpatasvir.

\section{USE IN SPECIFIC POPULATIONS}

\subsection{Pregnancy}

\section{Pregnancy Exposure Registry}

There is a pregnancy exposure registry that monitors pregnancy outcomes in women exposed to GENVOYA during pregnancy. Healthcare providers are encouraged to register patients by calling the Antiretroviral Pregnancy Registry (APR) at 1-800-2584263.

\section{Risk Summary}

There are insufficient human data on the use of GENVOYA during pregnancy to inform a drug-associated risk of birth defects and miscarriage. TAF use in women during pregnancy has not been evaluated; however, elvitegravir, cobicistat, and emtricitabine use during pregnancy has been evaluated in a limited number of women as reported to the APR. Available data from the APR through January 2016 show no birth defects reported for elvitegravir or cobicistat, and no difference in the risk of overall major birth defects for emtricitabine $(2.2 \%)$ compared with the background rate for major birth defects of $2.7 \%$ in a U.S. reference population of the Metropolitan Atlanta Congenital Defects Program (MACDP). The rate of miscarriage is not reported in the APR. The estimated background rate of miscarriage in the clinically recognized pregnancies in the U.S. general population is $15-20 \%$.

In animal studies, no adverse developmental effects were observed when the components of GENVOYA were administered separately during the period of organogenesis at exposures up to 23 and 0.2 times (rat and rabbits, respectively: elvitegravir), 1.6 and 3.8 times (rats and rabbits, respectively: cobicistat), 60 and 108 times (mice and rabbits, respectively; emtricitabine) and equal to and 53 times (rats and rabbits, respectively; TAF) the exposure at the recommended daily dosage of these components in GENVOYA [see Data]. Likewise, no adverse developmental effects were seen when elvitegravir or cobicistat was administered to rats through lactation at exposures up to 18 times or 1.2 times, respectively, the human exposure at the recommended therapeutic dose, and when emtricitabine was administered to mice through lactation at exposures up to approximately 60 times the exposure at the recommended daily dose. No adverse effects were observed in the offspring when TDF was administered through lactation at tenofovir exposures of approximately 14 times the exposure at the recommended daily dosage of GENVOYA. 


\section{Data}

\section{Human Data}

Elvitegravir: Based on prospective reports from the APR through January 2016 of 73 exposures to elvitegravir-containing regimens during pregnancy resulting in live births (including 51 exposed in the first trimester), there have been no birth defects reported.

Cobicistat: Based on prospective reports from the APR through January 2016 of 77 exposures to cobicistat-containing regimens during pregnancy resulting in live births (including 54 exposed in the first trimester), there have been no birth defects reported.

Emtricitabine: Based on prospective reports to the APR through January 2016 of 3155 exposures to emtricitabine-containing regimens during pregnancy resulting in live births (including 2145 exposed in the first trimester and 1010 exposed in the second/third trimester), there was no difference between FTC and overall birth defects compared with the background birth defect rate of $2.7 \%$ in the U.S. reference population of the MACDP. The prevalence of birth defects in live births was $2.2 \%(95 \% \mathrm{Cl}: 1.6 \%$ to $3.0 \%)$ with first trimester exposure to FTC-containing regimens and $2.1 \%(95 \% \mathrm{Cl}: 1.3 \%$ to $3.2 \%)$ with the second/third trimester exposure to emtricitabine-containing regimens.

\section{Animal Data}

\section{Elvitegravir:}

Elvitegravir was administered orally to pregnant rats (0,300, 1000, and 2000 $\mathrm{mg} / \mathrm{kg} /$ day $)$ and rabbits $(0,50,150$, and $450 \mathrm{mg} / \mathrm{kg} /$ day $)$ through organogenesis (on gestation days 7 through 17 and days 7 through 19, respectively). No significant toxicological effects were observed in embryo-fetal toxicity studies performed with elvitegravir in rats at exposures (AUC) approximately 23 times higher and in rabbits at approximately 0.2 times higher than human exposures at the recommended daily dose. In a pre/postnatal developmental study, elvitegravir was administered orally to rats at doses of $0,300,1000$, and $2000 \mathrm{mg} / \mathrm{kg}$ from gestation day 7 to day 20 of lactation. At doses of $2000 \mathrm{mg} / \mathrm{kg} /$ day of elvitegravir, neither maternal nor developmental toxicity was noted. Systemic exposures (AUC) at this dose were 18 times the human exposures at the recommended daily dose.

\section{Cobicistat:}

Cobicistat was administered orally to pregnant rats at doses of $0,25,50,125$ $\mathrm{mg} / \mathrm{kg} /$ day on gestation day 6 to 17 . Increases in postimplantation loss and decreased fetal weights were observed at a maternal toxic dose of $125 \mathrm{mg} / \mathrm{kg} / \mathrm{day}$. No malformations were noted at doses up to $125 \mathrm{mg} / \mathrm{kg} /$ day. Systemic exposures (AUC) at $50 \mathrm{mg} / \mathrm{kg} /$ day in pregnant females was 1.6 times higher than human exposures at the recommended daily dose. 
In pregnant rabbits, cobicistat was administered orally at doses of $0,20,50$, and $100 \mathrm{mg} / \mathrm{kg} /$ day during gestation days 7 to 20 . No maternal or embryo/fetal effects were noted at the highest dose of $100 \mathrm{mg} / \mathrm{kg} / \mathrm{day}$. Systemic exposures (AUC) at $100 \mathrm{mg} / \mathrm{kg} /$ day were 3.8 times higher than human exposures at the recommended daily dose.

In a pre/postnatal developmental study in rats, cobicistat was administered orally at doses of $0,10,30$, and $75 \mathrm{mg} / \mathrm{kg}$ from gestation day 6 to postnatal day 20, 21, or 22. At doses of $75 \mathrm{mg} / \mathrm{kg} /$ day of cobicistat, neither maternal nor developmental toxicity was noted. Systemic exposures (AUC) at this dose were 1.2 times the human exposures at the recommended daily dose.

\section{Emtricitabine:}

Emtricitabine was administered orally to pregnant mice $(250,500$, or 1000 $\mathrm{mg} / \mathrm{kg} /$ day) and rabbits $(100,300$, or $1000 \mathrm{mg} / \mathrm{kg} /$ day) through organogenesis (on gestation days 6 through 15, and 7 through 19, respectively). No significant toxicological effects were observed in embryo-fetal toxicity studies performed with emtricitabine in mice at exposures (AUC) approximately 60 times higher and in rabbits at approximately 108 times higher than human exposures at the recommended daily dose.

In a pre/postnatal development study with emtricitabine, mice were administered doses up to $1000 \mathrm{mg} / \mathrm{kg} /$ day; no significant adverse effects directly related to drug were observed in the offspring exposed daily from before birth (in utero) through sexual maturity at daily exposures (AUC) of approximately 60 times higher than human exposures at the recommended daily dose.

Tenofovir Alafenamide (TAF): TAF was administered orally to pregnant rats (25, 100 , or $250 \mathrm{mg} / \mathrm{kg} /$ day) and rabbits $(10,30$, or $100 \mathrm{mg} / \mathrm{kg} /$ day) through organogenesis (on gestation days 6 through 17, and 7 through 20, respectively). No adverse embryo-fetal effects were observed in rats and rabbits at TAF exposures similar to (rats) and approximately 53 (rabbits) times higher than the exposure in humans at the recommended daily dose of GENVOYA. TAF is rapidly converted to tenofovir; the observed tenofovir exposure in rats and rabbits were 59 (rats) and 93 (rabbits) times higher than human tenofovir exposures at the recommended daily doses. Since TAF is rapidly converted to tenofovir and a lower tenofovir exposure in rats and mice was observed after TAF administration compared to TDF administration, a pre/postnatal development study in rats was conducted only with TDF. Doses up to $600 \mathrm{mg} / \mathrm{kg} /$ day were administered through lactation; no adverse effects were observed in the offspring on gestation day 7 [and lactation day 20] at tenofovir exposures of approximately 14 [21] times higher than the exposures in humans at the recommended daily dose of GENVOYA. 


\subsection{Lactation}

\section{Risk Summary}

The Centers for Disease Control and Prevention recommend that HIV-infected mothers not breastfeed their infants to avoid risking postnatal transmission of HIV.

Emtricitabine has been shown to be present in human breast milk; it is unknown if elvitegravir, cobicistat, and TAF are present in human breast milk. Elvitegravir and cobicistat are present in rat milk, and tenofovir has been shown to be present in the milk of lactating rats and rhesus monkeys after administration of TDF [see Data]. It is unknown if TAF is present in animal milk.

It is not known if GENVOYA affects milk production or has effects on the breastfed child. Because of the potential for 1) HIV transmission (in HIV-negative infants); 2) developing viral resistance (in HIV-positive infants); and 3) adverse reactions a breastfed infant similar to those seen in adults, instruct mothers not to breastfeed if they are receiving GENVOYA.

\section{Data}

\section{Human Data}

Emtricitabine: Samples of breast milk obtained from five HIV-1 infected mothers show that emtricitabine is secreted in human milk. Breastfeeding infants whose mothers are being treated with emtricitabine may be at risk for developing viral resistance to emtricitabine. Other emtricitabine-associated risks in infants breastfed by mothers being treated with emtricitabine are unknown.

\section{Animal Data}

Elvitegravir: During the pre/postnatal developmental toxicology study at doses up to $2000 \mathrm{mg} / \mathrm{kg} /$ day a mean elvitegravir milk to plasma ratio of 0.1 was measured 30 minutes after administration to rats on lactation day 14.

Cobicistat: During the pre/postnatal developmental toxicology study at doses up to $75 \mathrm{mg} / \mathrm{kg} /$ day mean cobicistat milk to plasma ratio of up to 1.9 was measured 2 hours after administration to rats on lactation day 10.

Tenofovir Alafenamide: Studies in rats and monkeys have demonstrated that tenofovir is secreted in milk. During the pre/postnatal developmental toxicology study, tenofovir was excreted into the milk of lactating rats following oral administration of TDF (up to $600 \mathrm{mg} / \mathrm{kg} /$ day) at up to approximately $24 \%$ of the median plasma concentration in the highest dosed animals at lactation day 11. Tenofovir was excreted into the milk of lactating rhesus monkeys, following a single subcutaneous $(30 \mathrm{mg} / \mathrm{kg}$ ) dose of tenofovir, at concentrations up to approximately $4 \%$ of plasma concentration resulting in exposure (AUC) of approximately $20 \%$ of plasma exposure. 


\subsection{Pediatric Use}

The efficacy and safety of GENVOYA for the treatment of HIV-1 infection was established in pediatric patents aged 12 years and older with body weight greater than or equal to $35 \mathrm{~kg}$ [see Dosage and Administration (2.2)]. Use of GENVOYA in this age group is supported by studies in adults and by a 24-week open-label trial of 23 antiretroviral treatment-naïve HIV-1 infected pediatric subjects 12 to less than 18 years old treated with GENVOYA (Study 106). The safety and efficacy of GENVOYA in these subjects was similar to that in antiretroviral treatment-naïve adults [see Adverse Reactions (6.1), Clinical Pharmacology (12.3), and Clinical Studies (14.5)].

Safety and effectiveness of GENVOYA in pediatric patients less than 12 years of age or less than $35 \mathrm{~kg}$ have not been established.

\subsection{Geriatric Use}

Clinical trials of GENVOYA included 97 subjects ( 80 receiving GENVOYA) aged 65 years and over. No differences in safety or efficacy have been observed between elderly subjects and those between 12 and less than 65 years of age.

\subsection{Renal Impairment}

The pharmacokinetics, safety, and virologic and immunologic responses of GENVOYA in HIV-1 infected adult subjects with renal impairment (eGFR of 30 to $69 \mathrm{~mL}$ per minute by Cockcroft-Gault method) were evaluated in 248 subjects in an open-label trial, Study 112 [see Adverse Reactions (6.1) and Clinical Studies (14.4)].

GENVOYA is not recommended in patients with severe renal impairment (estimated creatinine clearance below $30 \mathrm{~mL}$ per minute). No dosage adjustment of GENVOYA is recommended in patients with estimated creatinine clearance greater than or equal to $30 \mathrm{~mL}$ per minute. The safety of GENVOYA has not been established in patients with estimated creatinine clearance that declines below $30 \mathrm{~mL}$ per minute [see Dosage and Administration (2.3), Warnings and Precautions (5.6) and Clinical Pharmacology (12.3)].

\subsection{Hepatic Impairment}

No dosage adjustment of GENVOYA is required in patients with mild (Child-Pugh Class A) or moderate (Child-Pugh Class B) hepatic impairment. GENVOYA has not been studied in patients with severe hepatic impairment (Child-Pugh Class C). Therefore, GENVOYA is not recommended for use in patients with severe hepatic impairment [see Dosage and Administration (2.4) and Clinical Pharmacology (12.3)].

\section{OVERDOSAGE}

No data are available on overdose of GENVOYA in patients. If overdose occurs, monitor the patient for evidence of toxicity. Treatment of overdose with GENVOYA 
consists of general supportive measures including monitoring of vital signs as well as observation of the clinical status of the patient.

Elvitegravir: Limited clinical experience is available at doses higher than the recommended dose of elvitegravir in GENVOYA. In one study, boosted elvitegravir equivalent to 2 times the therapeutic dose of $150 \mathrm{mg}$ once daily for 10 days was administered to 42 healthy subjects. No severe adverse reactions were reported. The effects of higher doses are not known. As elvitegravir is highly bound to plasma proteins, it is unlikely that it will be significantly removed by hemodialysis or peritoneal dialysis.

Cobicistat: Limited clinical experience is available at doses higher than the recommended dose of cobicistat in GENVOYA. In two studies, a single dose of cobicistat $400 \mathrm{mg}$ (2.7 times the dose in GENVOYA) was administered to a total of 60 healthy subjects. No severe adverse reactions were reported. The effects of higher doses are not known. As cobicistat is highly bound to plasma proteins, it is unlikely that it will be significantly removed by hemodialysis or peritoneal dialysis.

Emtricitabine: Limited clinical experience is available at doses higher than the recommended dose of emtricitabine in GENVOYA. In one clinical pharmacology study, single doses of emtricitabine $1200 \mathrm{mg}$ (6 times the dose in GENVOYA) were administered to 11 subjects. No severe adverse reactions were reported. The effects of higher doses are not known.

Hemodialysis treatment removes approximately $30 \%$ of the emtricitabine dose over a 3hour dialysis period starting within 1.5 hours of emtricitabine dosing (blood flow rate of $400 \mathrm{~mL}$ per minute and a dialysate flow rate of $600 \mathrm{~mL}$ per minute). It is not known whether emtricitabine can be removed by peritoneal dialysis.

Tenofovir alafenamide (TAF): Limited clinical experience is available at doses higher than the recommended dose of TAF in GENVOYA. A single dose of $125 \mathrm{mg}$ TAF (12.5 times the dose in GENVOYA) was administered to 48 healthy subjects; no serious adverse reactions were reported. The effects of higher doses are unknown. Tenofovir is efficiently removed by hemodialysis with an extraction coefficient of approximately $54 \%$.

\section{DESCRIPTION}

GENVOYA (elvitegravir, cobicistat, emtricitabine, and tenofovir alafenamide) is a fixeddose combination tablet containing elvitegravir, cobicistat, emtricitabine, and tenofovir alafenamide for oral administration.

- Elvitegravir is an HIV-1 integrase strand transfer inhibitor.

- Cobicistat is a mechanism-based inhibitor of cytochrome P450 (CYP) enzymes of the CYP3A family.

- Emtricitabine, a synthetic nucleoside analog of cytidine, is an HIV nucleoside analog reverse transcriptase inhibitor (HIV NRTI). 
- Tenofovir alafenamide, an HIV NRTI, is converted in vivo to tenofovir, an acyclic nucleoside phosphonate (nucleotide) analog of adenosine 5'-monophosphate.

Each tablet contains $150 \mathrm{mg}$ of elvitegravir, $150 \mathrm{mg}$ of cobicistat, $200 \mathrm{mg}$ of emtricitabine, and $10 \mathrm{mg}$ of tenofovir alafenamide (equivalent to $11.2 \mathrm{mg}$ of tenofovir alafenamide fumarate). The tablets include the following inactive ingredients: croscarmellose sodium, hydroxypropyl cellulose, lactose monohydrate, magnesium stearate, microcrystalline cellulose, silicon dioxide, and sodium lauryl sulfate. The tablets are film-coated with a coating material containing FD\&C Blue No. 2/indigo carmine aluminum lake, iron oxide yellow, polyethylene glycol, polyvinyl alcohol, talc, and titanium dioxide.

Elvitegravir: The chemical name of elvitegravir is 6-(3-chloro-2-fluorobenzyl)-1-[(2S)-1hydroxy-3-methylbutan-2-yl]-7-methoxy-4-oxo-1,4-dihydroquinoline-3-carboxylic acid.

It has a molecular formula of $\mathrm{C}_{23} \mathrm{H}_{23} \mathrm{CIFNO}_{5}$ and a molecular weight of 447.88 . It has the following structural formula:<smiles>COc1cc2c(cc1Cc1cccc(Cl)c1F)c(=O)c(C(=O)O)cn2[C@H](CO)C(C)C</smiles>

Elvitegravir is a white to pale yellow powder with a solubility of less than 0.3 micrograms per $\mathrm{mL}$ in water at $20^{\circ} \mathrm{C}$.

Cobicistat: The chemical name for cobicistat is 2,7,10,12-tetraazatridecanoic acid, 12methyl-13-[2-(1-methylethyl)-4-thiazolyl]-9-[2-(4-morpholinyl)ethyl]-8,11-dioxo-3,6bis(phenylmethyl)-, 5-thiazolylmethyl ester, (3R,6R,9S)-.

It has a molecular formula of $\mathrm{C}_{40} \mathrm{H}_{53} \mathrm{~N}_{7} \mathrm{O}_{5} \mathrm{~S}_{2}$ and a molecular weight of 776.02 . It has the following structural formula:<smiles>CC(C)c1nc(CN(C)C(=O)N[C@@H](CCN2CCOCC2)C(=O)N[C@H](CC[C@H](Cc2ccccc2)NC(=O)OCc2cncs2)Cc2ccccc2)cs1</smiles> 
Cobicistat is adsorbed onto silicon dioxide. Cobicistat on silicon dioxide drug substance is a white to pale yellow powder with a solubility of $0.1 \mathrm{mg}$ per $\mathrm{mL}$ in water at $20^{\circ} \mathrm{C}$.

Emtricitabine: The chemical name of emtricitabine is 4-amino-5-fluoro-1-(2Rhydroxymethyl-1,3-oxathiolan-5S-yl)-(1H)-pyrimidin-2-one. Emtricitabine is the (-)-enantiomer of a thio analog of cytidine, which differs from other cytidine analogs in that it has a fluorine in the 5 position.

It has a molecular formula of $\mathrm{C}_{8} \mathrm{H}_{10} \mathrm{FN}_{3} \mathrm{O}_{3} \mathrm{~S}$ and a molecular weight of 247.24. It has the following structural formula:<smiles>Nc1nc(=O)n([C@H]2CS[C@@H](CO)O2)cc1F</smiles>

Emtricitabine is a white to off-white powder with a solubility of approximately $112 \mathrm{mg}$ per $\mathrm{mL}$ in water at $25^{\circ} \mathrm{C}$.

Tenofovir alafenamide (TAF): The chemical name of tenofovir alafenamide fumarate drug substance is L-alanine, $N$-[(S)-[[(1R)-2-(6-amino-9H-purin-9-yl)-1methylethoxy]methyl]phenoxyphosphinyl]-, 1-methylethyl ester, (2E)-2-butenedioate $(2: 1)$.

It has an empirical formula of $\mathrm{C}_{21} \mathrm{H}_{29} \mathrm{O}_{5} \mathrm{~N}_{6} \mathrm{P} \cdot 1 / 2\left(\mathrm{C}_{4} \mathrm{H}_{4} \mathrm{O}_{4}\right)$ and a formula weight of 534.5. It has the following structural formula:<smiles>CC(C)OC(=O)[C@H](C)N[P@](=O)(CO[C@H](C)Cn1cnc2c(N)ncnc21)Oc1ccccc1</smiles>

Tenofovir alafenamide fumarate is a white to off-white or tan powder with a solubility of $4.7 \mathrm{mg}$ per $\mathrm{mL}$ in water at $20^{\circ} \mathrm{C}$.

\section{CLINICAL PHARMACOLOGY}

\subsection{Mechanism of Action}

GENVOYA is a fixed-dose combination of antiretroviral drugs elvitegravir (boosted by the CYP3A inhibitor cobicistat), emtricitabine, and tenofovir alafenamide [see Microbiology (12.4)]. 


\subsection{Pharmacodynamics}

Cardiac Electrophysiology

Thorough QT studies have been conducted for elvitegravir, cobicistat, and TAF. The effect of emtricitabine or the combination regimen GENVOYA on the QT interval is not known.

Elvitegravir: In a thorough QT/QTc study in 126 healthy subjects, elvitegravir (coadministered with $100 \mathrm{mg}$ ritonavir) $125 \mathrm{mg}$ and $250 \mathrm{mg} \mathrm{(0.83}$ and 1.67 times the dose in GENVOYA) did not affect the QT/QTc interval and did not prolong the PR interval.

Cobicistat: In a thorough QT/QTc study in 48 healthy subjects, a single dose of cobicistat $250 \mathrm{mg}$ and $400 \mathrm{mg}$ (1.67 and 2.67 times the dose in GENVOYA) did not affect the QT/QTc interval. Prolongation of the PR interval was noted in subjects receiving cobicistat. The maximum mean (95\% upper confidence bound) difference in PR from placebo after baseline-correction was 9.5 (12.1) $\mathrm{msec}$ for the $250 \mathrm{mg}$ cobicistat dose and 20.2 (22.8) for the $400 \mathrm{mg}$ cobicistat dose. Because the $150 \mathrm{mg}$ cobicistat dose used in the GENVOYA fixed-dose combination tablet is lower than the lowest dose studied in the thorough QT study, it is unlikely that treatment with GENVOYA will result in clinically relevant PR prolongation.

Tenofovir Alafenamide (TAF): In a thorough QT/QTc study in 48 healthy subjects, TAF at the therapeutic dose or at a supratherapeutic dose approximately 5 times the recommended therapeutic dose did not affect the QT/QTC interval and did not prolong the PR interval.

\section{Effects on Serum Creatinine}

The effect of cobicistat on serum creatinine was investigated in a Phase 1 study in subjects with an eGFR of at least $80 \mathrm{~mL}$ per minute $(\mathrm{N}=18)$ and with an eGFR of 50 to $79 \mathrm{~mL}$ per minute $(\mathrm{N}=12)$. A statistically significant change of eGFR $\mathrm{CG}_{\mathrm{CG}}$ from baseline was observed after 7 days of treatment with cobicistat $150 \mathrm{mg}$ among subjects with an eGFR of at least $80 \mathrm{~mL}$ per minute $(-9.9 \pm 13.1 \mathrm{~mL} / \mathrm{min})$ and subjects with an eGFR of 50 to $79 \mathrm{~mL}$ per minute $\left(-11.9 \pm 7.0 \mathrm{~mL}\right.$ per minute). These decreases in eGFR $\mathrm{CG}_{\mathrm{CG}}$ were reversible after cobicistat was discontinued. The actual glomerular filtration rate, as determined by the clearance of probe drug iohexol, was not altered from baseline following treatment of cobicistat among subjects with an eGFR of at least $50 \mathrm{~mL}$ per minute, indicating cobicistat inhibits tubular secretion of creatinine, reflected as a reduction in eGFR $R_{\mathrm{CG}}$, without affecting the actual glomerular filtration rate. 


\subsection{Pharmacokinetics}

\section{Absorption, Distribution, Metabolism, and Excretion}

The pharmacokinetic (PK) properties of the components of GENVOYA are provided in Table 6. The multiple dose PK parameters of elvitegravir, cobicistat, emtricitabine, TAF and its metabolite tenofovir are provided in Table 7.

Table 6 Pharmacokinetic Properties of the Components of GENVOYA

\begin{tabular}{|c|c|c|c|c|}
\hline & Elvitegravir & Cobicistat & Emtricitabine & TAF \\
\hline \multicolumn{5}{|l|}{ Absorption } \\
\hline $\mathrm{T}_{\max }(\mathrm{h})$ & 4 & 3 & 3 & 1 \\
\hline $\begin{array}{l}\text { Effect of light meal (relative } \\
\text { to fasting): AUC Ratio }{ }^{a}\end{array}$ & $\begin{array}{c}1.34 \\
(1.19,1.51)\end{array}$ & $\begin{array}{c}1.03 \\
(0.90,1.17)\end{array}$ & $\begin{array}{c}0.95 \\
(0.91,1.00)\end{array}$ & $\begin{array}{c}1.15 \\
(1.07,1.24)\end{array}$ \\
\hline $\begin{array}{l}\text { Effect of high fat meal } \\
\text { (relative to fasting): AUC } \\
\text { Ratio }^{a}\end{array}$ & $\begin{array}{c}1.87 \\
(1.66,2.10)\end{array}$ & $\begin{array}{c}0.83 \\
(0.73,0.95)\end{array}$ & $\begin{array}{c}0.96 \\
(0.92,1.00)\end{array}$ & $\begin{array}{c}1.18 \\
(1.09,1.26)\end{array}$ \\
\hline \multicolumn{5}{|l|}{ Distribution } \\
\hline $\begin{array}{l}\text { \% Bound to human plasma } \\
\text { proteins }\end{array}$ & $\sim 99$ & $\sim 98$ & $<4$ & $\sim 80$ \\
\hline $\begin{array}{l}\text { Source of protein binding } \\
\text { data }\end{array}$ & Ex vivo & In vitro & In vitro & Ex vivo \\
\hline Blood-to-plasma ratio & 0.73 & 0.5 & 0.6 & 1.0 \\
\hline \multicolumn{5}{|l|}{ Metabolism } \\
\hline Metabolism & $\begin{array}{l}\text { CYP3A (major) } \\
\text { UGT1A1/3 } \\
\text { (minor) }\end{array}$ & $\begin{array}{l}\text { CYP3A (major) } \\
\text { CYP2D6 (minor) }\end{array}$ & $\begin{array}{l}\text { Not significantly } \\
\text { metabolized }\end{array}$ & $\begin{array}{c}\text { Cathepsin } A^{b} \\
\text { (PBMCs) } \\
\text { CES1 } \\
\text { (hepatocytes) } \\
\text { CYP3A (minimal) }\end{array}$ \\
\hline \multicolumn{5}{|l|}{ Elimination } \\
\hline Major route of elimination & Metabolism & Metabolism & $\begin{array}{l}\text { Glomerular } \\
\text { filtration and } \\
\text { active tubular } \\
\text { secretion }\end{array}$ & $\begin{array}{l}\text { Metabolism } \\
\text { (>80\% of oral } \\
\text { dose })\end{array}$ \\
\hline $\mathrm{t}_{1 / 2}(\mathrm{~h})^{\mathrm{c}}$ & 12.9 & 3.5 & 10 & 0.51 \\
\hline $\begin{array}{l}\% \text { Of dose excreted in } \\
\text { urine }^{d}\end{array}$ & 6.7 & 8.2 & 70 & $<1 \%$ \\
\hline $\begin{array}{l}\text { \% Of dose excreted in } \\
\text { feces }^{d}\end{array}$ & 94.8 & 86.2 & 13.7 & 31.7 \\
\hline
\end{tabular}

PBMCs = peripheral blood mononuclear cells; CES1 = carboxylesterase 1.

a. Values refer to geometric mean ratio in AUC [fed / fasted] and (90\% confidence interval). Elvitegravir light meal= 373 kcal, 20\% fat; GENVOYA light meal= 400 kcal, 20\% fat; elvitegravir and GENVOYA high fat meal $=\sim 800 \mathrm{kcal}, 50 \%$ fat. Based on the effect of food on elvitegravir, GENVOYA should be taken with food.

b. In vivo, TAF is hydrolyzed within cells to form tenofovir (major metabolite), which is phosphorylated to the active metabolite, tenofovir diphosphate. In vitro studies have shown that TAF is metabolized to tenofovir by cathepsin A in PBMCs and macrophages; and by CES1 in hepatocytes. Upon coadministration with the moderate CYP3A inducer probe efavirenz, TAF exposure was not significantly affected.

c. $t_{1 / 2}$ values refer to median terminal plasma half-life. Note that the pharmacologically active metabolite, tenofovir diphosphate, has a half-life of 150-180 hours within PBMCs.

d. Dosing in mass balance studies: elvitegravir (single dose administration of $\left[{ }^{14} \mathrm{C}\right]$ elvitegravir coadministered with $100 \mathrm{mg}$ ritonavir); cobicistat (single dose administration of $\left[{ }^{14} \mathrm{C}\right]$ cobicistat after multiple dosing of cobicistat for six days); emtricitabine (single dose administration of $\left[{ }^{14} \mathrm{C}\right]$ emtricitabine after multiple dosing of emtricitabine for ten days); TAF (single dose administration of $\left[{ }^{14} \mathrm{C}\right] \mathrm{TAF}$ ). 
Table 7 Multiple Dose Pharmacokinetic Parameters of Elvitegravir, Cobicistat, Emtricitabine, Tenofovir Alafenamide (TAF) and its Metabolite Tenofovir Following Oral Administration of GENVOYA with Food in HIV-Infected Adults

\begin{tabular}{|l|c|c|c|c|c|}
\hline $\begin{array}{c}\text { Parameter } \\
\text { Mean (CV\%) }\end{array}$ & Elvitegravir $^{\mathrm{a}}$ & Cobicistat $^{\mathrm{a}}$ & Emtricitabine $^{\mathrm{a}}$ & TAF $^{\mathrm{b}}$ & Tenofovir $^{\mathrm{c}}$ \\
\hline $\begin{array}{l}\mathrm{C}_{\text {max }} \\
(\mathrm{microgram} \text { per } \\
\mathrm{mL})\end{array}$ & $2.1(33.7)$ & $1.5(28.4)$ & $2.1(20.2)$ & $0.16(51.1)$ & $0.02(26.1)$ \\
\hline $\begin{array}{l}\text { AUC } \\
(\mathrm{microg} \\
\text { per mL) }\end{array}$ & $22.8(34.7)$ & $9.5(33.9)$ & $11.7(16.6)$ & $0.21(71.8)$ & $0.29(27.4)$ \\
\hline $\begin{array}{l}\mathrm{C}_{\text {trough }} \\
(\mathrm{microgram} \text { per } \\
\mathrm{mL})\end{array}$ & $0.29(61.7)$ & $0.02(85.2)$ & $0.10(46.7)$ & $\mathrm{NA}$ & $0.01(28.5)$ \\
\hline
\end{tabular}

$\mathrm{CV}=$ Coefficient of Variation; NA = Not Applicable

a. From Intensive PK analysis in Study 102, $\mathrm{N}=19$

b. From Population PK analysis in Studies 104 and 111, N=539

c. From Population PK analysis in Studies 104 and 111, N=841

Special Populations

Patients with Renal Impairment

The pharmacokinetics of GENVOYA in HIV-1 infected subjects with renal impairment (eGFR of 30 to $69 \mathrm{~mL}$ per minute by Cockcroft-Gault method) were evaluated in a subset of virologically suppressed subjects in an open-label trial, Study 112 (Table 8). 
Table 8 Pharmacokinetics of GENVOYA in HIV-Infected Adults with Renal Impairment as Compared to Subjects with Normal Renal Function

\begin{tabular}{|c|c|c|c|}
\hline & \multicolumn{3}{|c|}{$\begin{array}{c}\text { AUC }_{\text {tau }} \\
\text { (microgram•hour per mL) } \\
\text { Mean (CV\%) }\end{array}$} \\
\hline Creatinine Clearance & $\begin{array}{c}\geq \mathbf{9 0} \mathbf{m L} \text { per } \\
\text { minute (N=18) }\end{array}$ & $\begin{array}{c}\mathbf{6 0 - 8 9 ~} \mathbf{m L} \text { per } \\
\text { minute (N=11) }\end{array}$ & $\begin{array}{c}\mathbf{3 0 - 5 9 ~ m L ~ p e r ~} \\
\text { minute (N=18) }\end{array}$ \\
\hline Elvitegravir & $22.6(35.8)$ & $24.2(35.0)$ & $29.0(29.6)$ \\
\hline Cobicistat & $9.4(35.0)$ & $10.0(47.5)$ & $9.9(45.0)$ \\
\hline Emtricitabine & $11.4(11.9)$ & $17.6(18.2)$ & $23.0(23.6)$ \\
\hline Tenofovir Alafenamide* $^{*}$ & $0.23(47.2)$ & $0.24(45.6)$ & $0.26(58.8)$ \\
\hline Tenofovir & $0.32(14.9)$ & $0.46(31.5)$ & $0.61(28.4)$ \\
\hline
\end{tabular}

${ }^{\star} \mathrm{AUC} \mathrm{C}_{\text {last }}$

a. From a Phase 2 study in HIV-infected adults with normal renal function.

b. These subjects from Study 112 had an eGFR ranging from 60 to $69 \mathrm{~mL}$ per minute.

c. Study 112.

Patients with Hepatic Impairment

Elvitegravir and Cobicistat: A study of the pharmacokinetics of cobicistat-boosted elvitegravir was performed in healthy subjects and subjects with moderate hepatic impairment. No clinically relevant differences in elvitegravir or cobicistat pharmacokinetics were observed between subjects with moderate hepatic impairment (Child-Pugh Class B) and healthy subjects [see Use in Specific Populations (8.7)].

Emtricitabine: The pharmacokinetics of emtricitabine has not been studied in subjects with hepatic impairment; however, emtricitabine is not significantly metabolized by liver enzymes, so the impact of liver impairment should be limited.

Tenofovir Alafenamide (TAF): Clinically relevant changes in tenofovir pharmacokinetics in subjects with hepatic impairment were not observed in subjects with mild to moderate (Child-Pugh Class A and B) hepatic impairment [see Use in Specific Populations (8.7)].

Hepatitis B and/or Hepatitis C Virus Co-infection

Elvitegravir: Limited data from population pharmacokinetic analysis $(\mathrm{N}=24)$ indicated that hepatitis $B$ and/or $C$ virus infection had no clinically relevant effect on the exposure of cobicistat-boosted elvitegravir.

Cobicistat: There were insufficient pharmacokinetic data in the clinical trials to determine the effect of hepatitis $B$ and/or $C$ virus infection on the pharmacokinetics of cobicistat.

Emtricitabine and Tenofovir Alafenamide (TAF): Pharmacokinetics of emtricitabine and TAF have not been fully evaluated in subjects coinfected with hepatitis $B$ and/or $C$ virus. 


\section{Pediatric Patients}

Exposures of TAF achieved in 24 pediatric subjects aged 12 to less than 18 years who received GENVOYA in Study 106 were decreased (23\% for AUC) compared to exposures achieved in treatment-naïve adults following administration of GENVOYA, but were overall deemed acceptable based on exposure-response relationships; the other components of GENVOYA had similar exposures in adolescents compared to treatment-naïve adults [see Use in Specific Populations (8.4)].

\section{Geriatric Patients}

Pharmacokinetics of elvitegravir, cobicistat, emtricitabine and tenofovir have not been fully evaluated in the elderly (65 years of age and older). Population pharmacokinetics analysis of HIV-infected subjects in Phase 2 and Phase 3 trials of GENVOYA showed that age did not have a clinically relevant effect on exposures of TAF up to 75 years of age [see Use in Specific Populations (8.5)].

Race

Based on population pharmacokinetic analyses, no dosage adjustment is recommended based on race.

Gender

Based on population pharmacokinetic analyses, no dosage adjustment is recommended based on gender.

\section{Drug Interaction Studies}

[see also Contraindications (4) and Drug Interactions (7)]

The drug-drug interaction studies described in Tables 9-11 were conducted with GENVOYA, elvitegravir (coadministered with cobicistat or ritonavir), cobicistat administered alone, or TAF administered alone.

As GENVOYA should not be administered with other antiretroviral medications, information regarding drug-drug interactions with other antiretrovirals agents is not provided.

The effects of coadministered drugs on the exposure of elvitegravir are shown in Table 9. The effects of coadministered drugs on the exposure of TAF are shown in Table 10. The effects of GENVOYA or its components on the exposure of coadministered drugs are shown in Table 11. For information regarding clinical recommendations, see Drug Interactions (7). 
Table 9 Drug Interactions: Changes in Pharmacokinetic Parameters for Elvitegravir in the Presence of the Coadministered Drug ${ }^{\mathrm{a}}$

\begin{tabular}{|c|c|c|c|c|c|c|c|}
\hline \multirow[t]{2}{*}{$\begin{array}{c}\text { Coadministered } \\
\text { Drug }\end{array}$} & \multirow[t]{2}{*}{$\begin{array}{c}\text { Dose of } \\
\text { Coadministered } \\
\text { Drug (mg) }\end{array}$} & \multirow[t]{2}{*}{$\begin{array}{l}\text { Elvitegravir } \\
\text { Dose (mg) }\end{array}$} & \multirow[t]{2}{*}{$\begin{array}{l}\text { Cobicistat or } \\
\text { Ritonavir } \\
\text { Booster } \\
\text { Dose (mg) }\end{array}$} & \multirow[t]{2}{*}{$\mathbf{N}$} & \multicolumn{3}{|c|}{$\begin{array}{c}\text { Mean Ratio of Elvitegravir } \\
\text { Pharmacokinetic } \\
\text { Parameters }(90 \% \mathrm{Cl}) \\
\text { No effect }=1.00\end{array}$} \\
\hline & & & & & $\mathrm{C}_{\max }$ & $A \cup C$ & $\mathrm{C}_{\min }$ \\
\hline \multirow{4}{*}{ Antacids } & $\begin{array}{c}20 \mathrm{~mL} \text { single } \\
\text { dose given } 4 \\
\text { hours before } \\
\text { elvitegravir }\end{array}$ & \multirow{4}{*}{$\begin{array}{l}50 \text { single } \\
\text { dose }\end{array}$} & \multirow{4}{*}{$\begin{array}{l}\text { Ritonavir } \\
100 \text { single } \\
\text { dose }\end{array}$} & 8 & $\begin{array}{c}0.95 \\
(0.84,1.07)\end{array}$ & $\begin{array}{c}0.96 \\
(0.88,1.04)\end{array}$ & $\begin{array}{c}1.04 \\
(0.93,1.17)\end{array}$ \\
\hline & $\begin{array}{c}20 \mathrm{~mL} \text { single } \\
\text { dose given } 4 \\
\text { hours after } \\
\text { elvitegravir }\end{array}$ & & & 10 & $\begin{array}{c}0.98 \\
(0.88,1.10)\end{array}$ & $\begin{array}{c}0.98 \\
(0.91,1.06)\end{array}$ & $\begin{array}{c}1.00 \\
(0.90,1.11)\end{array}$ \\
\hline & $\begin{array}{c}20 \mathrm{~mL} \text { single } \\
\text { dose given } 2 \\
\text { hours before } \\
\text { elvitegravir }\end{array}$ & & & 11 & $\begin{array}{c}0.82 \\
(0.74,0.91)\end{array}$ & $\begin{array}{c}0.85 \\
(0.79,0.91)\end{array}$ & $\begin{array}{c}0.90 \\
(0.82,0.99)\end{array}$ \\
\hline & $\begin{array}{c}20 \mathrm{~mL} \text { single } \\
\text { dose given } 2 \\
\text { hours after } \\
\text { elvitegravir }\end{array}$ & & & 10 & $\begin{array}{c}0.79 \\
(0.71,0.88)\end{array}$ & $\begin{array}{c}0.80 \\
(0.75,0.86)\end{array}$ & $\begin{array}{c}0.80 \\
(0.73,0.89)\end{array}$ \\
\hline Carbamazepine & 200 twice daily & $\begin{array}{l}150 \text { once } \\
\text { daily }\end{array}$ & $\begin{array}{c}\text { Cobicistat } \\
150 \text { once daily }\end{array}$ & 12 & $\begin{array}{c}0.55 \\
(0.49,0.61)\end{array}$ & $\begin{array}{c}0.31 \\
(0.28,0.33) \\
\end{array}$ & $\begin{array}{c}0.03 \\
(0.02,0.40)\end{array}$ \\
\hline \multirow[b]{2}{*}{ Famotidine } & $\begin{array}{l}40 \text { once daily } \\
\text { given } 12 \text { hours } \\
\text { after elvitegravir }\end{array}$ & \multirow{2}{*}{$\begin{array}{c}150 \text { once } \\
\text { daily }\end{array}$} & \multirow{2}{*}{$\mid \begin{array}{c}\text { Cobicistat } \\
150 \text { once daily }\end{array}$} & 10 & $\begin{array}{c}1.02 \\
(0.89,1.17)\end{array}$ & $\begin{array}{c}1.03 \\
(0.95,1.13)\end{array}$ & $\begin{array}{c}1.18 \\
(1.05,1.32)\end{array}$ \\
\hline & $\begin{array}{l}40 \text { once daily } \\
\text { given } \\
\text { simultaneously } \\
\text { with elvitegravir }\end{array}$ & & & 16 & $\begin{array}{c}1.00 \\
(0.92,1.10)\end{array}$ & $\begin{array}{c}1.03 \\
(0.98,1.08)\end{array}$ & $\begin{array}{c}1.07 \\
(0.98,1.17)\end{array}$ \\
\hline Ketoconazole & 200 twice daily & $\begin{array}{c}150 \text { once } \\
\text { daily }\end{array}$ & $\begin{array}{c}\text { Ritonavir } \\
100 \text { once daily }\end{array}$ & 18 & $\begin{array}{c}1.17 \\
(1.04,1.33) \\
\end{array}$ & $\begin{array}{c}1.48 \\
(1.36,1.62) \\
\end{array}$ & $\begin{array}{c}1.67 \\
(1.48,1.88) \\
\end{array}$ \\
\hline $\begin{array}{l}\text { Ledipasvir/ } \\
\text { Sofosbuvir }\end{array}$ & $\begin{array}{l}90 / 400 \text { once } \\
\text { daily }\end{array}$ & $\begin{array}{l}150 \text { once } \\
\text { daily }^{b}\end{array}$ & $\begin{array}{c}\text { Cobicistat } \\
150 \text { once } \\
\text { daily }^{b}\end{array}$ & 30 & $\begin{array}{c}0.98 \\
(0.90,1.07)\end{array}$ & $\begin{array}{c}1.11 \\
(1.02,1.20)\end{array}$ & $\begin{array}{c}1.46 \\
(1.28,1.66)\end{array}$ \\
\hline \multirow{3}{*}{ Omeprazole } & $\begin{array}{l}40 \text { once daily } \\
\text { given } 2 \text { hours } \\
\text { before } \\
\text { elvitegravir }\end{array}$ & 50 once daily & $\begin{array}{c}\text { Ritonavir } \\
100 \text { once daily }\end{array}$ & 9 & $\begin{array}{c}0.93 \\
(0.83,1.04)\end{array}$ & $\begin{array}{c}0.99 \\
(0.91,1.07)\end{array}$ & $\begin{array}{c}0.94 \\
(0.85,1.04)\end{array}$ \\
\hline & $\begin{array}{l}20 \text { once daily } \\
\text { given } 2 \text { hours } \\
\text { before } \\
\text { elvitegravir }\end{array}$ & \multirow[t]{2}{*}{$\begin{array}{l}150 \text { once } \\
\text { daily }\end{array}$} & \multirow[t]{2}{*}{$\begin{array}{c}\text { Cobicistat } \\
150 \text { once daily }\end{array}$} & 11 & $\begin{array}{c}1.16 \\
(1.04,1.30)\end{array}$ & $\mid \begin{array}{c}1.10 \\
(1.02,1.19)\end{array}$ & $\begin{array}{c}1.13 \\
(0.96,1.34)\end{array}$ \\
\hline & $\begin{array}{l}20 \text { once daily } \\
\text { given } 12 \text { hours }\end{array}$ & & & 11 & $\begin{array}{c}1.03 \\
(0.92,1.15)\end{array}$ & $\begin{array}{c}1.05 \\
(0.93,1.18)\end{array}$ & $\begin{array}{c}1.10 \\
(0.92,1.32)\end{array}$ \\
\hline
\end{tabular}




\begin{tabular}{|c|c|c|c|c|c|c|c|}
\hline \multirow[t]{3}{*}{$\begin{array}{c}\text { Coadministered } \\
\text { Drug }\end{array}$} & \multirow[t]{2}{*}{$\begin{array}{l}\text { Dose of } \\
\text { Coadministered } \\
\text { Drug (mg) }\end{array}$} & \multirow[t]{3}{*}{$\begin{array}{l}\text { Elvitegravir } \\
\text { Dose (mg) }\end{array}$} & \multirow[t]{3}{*}{$\begin{array}{l}\text { Cobicistat or } \\
\text { Ritonavir } \\
\text { Booster } \\
\text { Dose }(\mathbf{m g})\end{array}$} & \multirow[t]{3}{*}{$\mathbf{N}$} & \multicolumn{3}{|c|}{$\begin{array}{c}\text { Mean Ratio of Elvitegravir } \\
\text { Pharmacokinetic } \\
\text { Parameters }(90 \% \mathrm{Cl}) \\
\text { No effect }=1.00\end{array}$} \\
\hline & & & & & $\mathrm{C}_{\max }$ & AUC & $\mathrm{C}_{\min }$ \\
\hline & after elvitegravir & & & & & & \\
\hline Rifabutin & $\begin{array}{c}150 \text { once every } \\
\text { other day }\end{array}$ & $\begin{array}{l}150 \text { once } \\
\text { daily }\end{array}$ & $\begin{array}{c}\text { Cobicistat } \\
150 \text { once daily }\end{array}$ & 12 & $\begin{array}{c}0.91 \\
(0.84,0.99)\end{array}$ & $\begin{array}{c}0.79 \\
(0.74,0.85)\end{array}$ & $\begin{array}{c}0.33 \\
(0.27,0.40)\end{array}$ \\
\hline Rosuvastatin & 10 single dose & $\begin{array}{l}150 \text { once } \\
\text { daily }\end{array}$ & $\begin{array}{c}\text { Cobicistat } \\
150 \text { once daily }\end{array}$ & 10 & $\begin{array}{c}0.94 \\
(0.83,1.07)\end{array}$ & $\begin{array}{c}1.02 \\
(0.91,1.14)\end{array}$ & $\begin{array}{c}0.98 \\
(0.83,1.16)\end{array}$ \\
\hline Sertraline & 50 single dose & $\begin{array}{l}150 \text { once } \\
\text { daily }^{b}\end{array}$ & $\begin{array}{l}\text { Cobicistat } \\
150 \text { once } \\
\text { daily }^{\mathrm{b}}\end{array}$ & 19 & $\begin{array}{c}0.88 \\
(0.82,0.93)\end{array}$ & $\begin{array}{c}0.94 \\
(0.89,0.98)\end{array}$ & $\begin{array}{c}0.99 \\
(0.93,1.05)\end{array}$ \\
\hline $\begin{array}{l}\text { Sofosbuvir/ } \\
\text { Velpatasvir }\end{array}$ & $\begin{array}{l}\text { 400/100 once } \\
\text { daily }\end{array}$ & $\begin{array}{l}150 \text { once } \\
\text { daily }^{b}\end{array}$ & $\begin{array}{l}\text { Cobicistat } \\
150 \text { once } \\
\text { daily }^{b}\end{array}$ & 24 & $\begin{array}{c}0.87 \\
(0.80,0.94)\end{array}$ & $\begin{array}{c}0.94 \\
(0.88,1.00)\end{array}$ & $\begin{array}{c}1.08 \\
(0.97,1.20)\end{array}$ \\
\hline
\end{tabular}

a. All interaction studies conducted in healthy volunteers.

b. Study conducted with GENVOYA.

Table 10 Drug Interactions: Changes in Pharmacokinetic Parameters for Tenofovir Alafenamide (TAF) in the Presence of the Coadministered Drug $^{\mathrm{a}}$

\begin{tabular}{|l|c|c|c|c|c|c|}
\hline $\begin{array}{l}\text { Coadministered } \\
\text { Drug }\end{array}$ & $\begin{array}{c}\text { Dose of } \\
\text { Coadministered } \\
\text { Drug (mg) }\end{array}$ & TAF (mg) & N & \multicolumn{3}{|c|}{$\begin{array}{l}\text { Mean Ratio of TAF Pharmacokinetic } \\
\text { Parameters (90\% Cl); No effect = 1.00 }\end{array}$} \\
\cline { 4 - 7 } & 150 once daily & 8 once daily & 12 & $\begin{array}{c}2.83 \\
(2.20,3.65)\end{array}$ & $\begin{array}{c}2.65 \\
(2.29,3.07)\end{array}$ & $\mathrm{NC}$ \\
\hline Cobicistat & $90 / 400$ once daily & 10 once daily & 30 & $\begin{array}{c}0.90 \\
(0.73,1.11)\end{array}$ & $\begin{array}{c}0.86 \\
(0.78,0.95)\end{array}$ & $\mathrm{NC}$ \\
\hline $\begin{array}{l}\text { Ledipasvir/ } \\
\text { Sofosbuvir }\end{array}$ & 50 single dose & 10 once daily $^{\mathrm{b}}$ & 19 & $\begin{array}{c}1.00 \\
(0.86,1.16)\end{array}$ & $\begin{array}{c}0.96 \\
(0.89,1.03)\end{array}$ & $\mathrm{NC}$ \\
\hline Sertraline & $400 / 100$ once daily & 10 once daily $^{\mathrm{b}}$ & 24 & $\begin{array}{c}0.80 \\
(0.68,0.94)\end{array}$ & $\begin{array}{c}0.87 \\
(0.81,0.94)\end{array}$ & $\mathrm{NC}$ \\
\hline $\begin{array}{l}\text { Sofosbuvir/ } \\
\text { Velpatasvir }\end{array}$ & & & & & \\
\hline
\end{tabular}

$\mathrm{NC}=$ Not Calculated

a. All interaction studies conducted in healthy volunteers.

b. Study conducted with GENVOYA. 
Table 11 Drug Interactions: Changes in Pharmacokinetic Parameters for Coadministered Drug in the Presence of GENVOYA or the Individual Components $^{\mathrm{a}}$

\begin{tabular}{|c|c|c|c|c|c|c|c|}
\hline \multirow[t]{2}{*}{$\underset{\text { Drug }}{\text { Coadministered }}$} & \multirow[t]{2}{*}{$\begin{array}{c}\text { Dose of } \\
\text { Coadministered } \\
\text { Drug (mg) }\end{array}$} & \multirow[t]{2}{*}{$\begin{array}{l}\text { Elvitegravir } \\
\text { Dose (mg) }\end{array}$} & \multirow[t]{2}{*}{$\begin{array}{l}\text { Cobicistat } \\
\text { Booster } \\
\text { Dose (mg) }\end{array}$} & \multirow[t]{2}{*}{$\mathbf{N}$} & \multicolumn{3}{|c|}{$\begin{array}{c}\text { Mean Ratio of Coadministered } \\
\text { Drug Pharmacokinetic } \\
\text { Parameters }(90 \% \mathrm{Cl}) \\
\text { No effect }=1.00\end{array}$} \\
\hline & & & & & $\mathrm{C}_{\max }$ & AUC & $\mathrm{C}_{\min }$ \\
\hline Buprenorphine & \multirow{2}{*}{$\begin{array}{c}16-24 \text { once } \\
\text { daily }\end{array}$} & \multirow{2}{*}{$\begin{array}{l}150 \text { once } \\
\text { daily }\end{array}$} & \multirow{2}{*}{$\begin{array}{l}150 \text { once } \\
\text { daily }\end{array}$} & \multirow{2}{*}{17} & $\begin{array}{c}1.12 \\
(0.98,1.27) \\
\end{array}$ & $\begin{array}{c}1.35 \\
(1.18,1.55) \\
\end{array}$ & $\begin{array}{c}1.66 \\
(1.43,1.93) \\
\end{array}$ \\
\hline Norbuprenorphine & & & & & $\begin{array}{c}1.24 \\
(1.03,1.49)\end{array}$ & $\begin{array}{c}1.42 \\
(1.22,1.67)\end{array}$ & $\begin{array}{c}1.57 \\
(1.31,1.88)\end{array}$ \\
\hline Carbamazepine & \multirow{2}{*}{200 twice daily } & \multirow{2}{*}{$\begin{array}{l}150 \text { once } \\
\text { daily }\end{array}$} & \multirow{2}{*}{$\begin{array}{c}150 \text { once } \\
\text { daily }\end{array}$} & \multirow{2}{*}{12} & $\begin{array}{c}1.40 \\
(1.32,1.49)\end{array}$ & $\begin{array}{c}1.43 \\
(1.36,1.52)\end{array}$ & $\begin{array}{c}1.51 \\
(1.41,1.62)\end{array}$ \\
\hline $\begin{array}{l}\text { Carbamazepine- } \\
\text { 10,11-epoxide }\end{array}$ & & & & & $\begin{array}{c}0.73 \\
(0.70,0.78)\end{array}$ & $\begin{array}{c}0.65 \\
(0.63,0.66)\end{array}$ & $\begin{array}{c}0.59 \\
(0.57,0.61)\end{array}$ \\
\hline Desipramine & 50 single dose & $\mathrm{N} / \mathrm{A}$ & $\begin{array}{l}150 \text { once } \\
\text { daily }\end{array}$ & 8 & $\begin{array}{c}1.24 \\
(1.08,1.44)\end{array}$ & $\begin{array}{c}1.65 \\
(1.36,2.02)\end{array}$ & NC \\
\hline Digoxin & 0.5 single dose & $\mathrm{N} / \mathrm{A}$ & $\begin{array}{l}150 \text { once } \\
\text { daily }\end{array}$ & 22 & $\begin{array}{c}1.41 \\
(1.29,1.55)\end{array}$ & $\begin{array}{c}1.08 \\
(1.00,1.17)\end{array}$ & NC \\
\hline Ledipasvir & 90 once daily & \multirow{3}{*}{$\begin{array}{l}150 \text { once } \\
\text { daily }^{c}\end{array}$} & \multirow{3}{*}{$\begin{array}{l}150 \text { once }^{\text {daily }} \\
\text { d }^{c}\end{array}$} & \multirow{3}{*}{30} & $\begin{array}{c}1.65 \\
(1.53,1.78)\end{array}$ & $\begin{array}{c}1.79 \\
(1.64,1.96)\end{array}$ & $\begin{array}{c}1.93 \\
(1.74,2.15)\end{array}$ \\
\hline Sofosbuvir & \multirow{2}{*}{400 once daily } & & & & $\begin{array}{c}1.28 \\
(1.13,1.47)\end{array}$ & $\begin{array}{c}1.47 \\
(1.35,1.59)\end{array}$ & N/A \\
\hline GS-331007 & & & & & $\begin{array}{c}1.29 \\
(1.24,1.35)\end{array}$ & $\begin{array}{c}1.48 \\
(1.44,1.53) \\
\end{array}$ & $\begin{array}{c}1.66 \\
(1.60,1.73)\end{array}$ \\
\hline Naloxone & 4-6 once daily & $\begin{array}{l}150 \text { once } \\
\text { daily }\end{array}$ & $\begin{array}{l}150 \text { once } \\
\text { daily }\end{array}$ & 17 & $\begin{array}{c}0.72 \\
(0.61,0.85)\end{array}$ & $\begin{array}{c}0.72 \\
(0.59,0.87)\end{array}$ & N/A \\
\hline \multirow{2}{*}{$\begin{array}{l}\text { Norgestimate/ } \\
\text { ethinyl estradiol }\end{array}$} & $\begin{array}{l}0.180 / 0.215 / \\
0.250 \\
\text { norgestimate } \\
\text { once daily }\end{array}$ & \multirow{2}{*}{$\begin{array}{l}150 \text { once }^{-} \\
\text {daily }^{d}\end{array}$} & \multirow{2}{*}{$\begin{array}{l}150 \text { once } \\
\text { daily }^{d}\end{array}$} & \multirow[t]{2}{*}{13} & $\begin{array}{c}2.08 \\
(2.00,2.17)\end{array}$ & $\begin{array}{c}2.26 \\
(2.15,2.37)\end{array}$ & $\begin{array}{c}2.67 \\
(2.43,2.92)\end{array}$ \\
\hline & $\begin{array}{l}0.025 \text { ethinyl } \\
\text { estradiol once } \\
\text { daily }\end{array}$ & & & & $\begin{array}{c}0.94 \\
(0.86,1.04)\end{array}$ & $\begin{array}{c}0.75 \\
(0.69,0.81)\end{array}$ & $\begin{array}{c}0.56 \\
(0.52,0.61)\end{array}$ \\
\hline R-Methadone & \multirow{2}{*}{ 80-120 daily } & \multirow{2}{*}{$\begin{array}{l}150 \text { once } \\
\text { daily }\end{array}$} & \multirow{2}{*}{$\begin{array}{l}150 \text { once } \\
\text { daily }\end{array}$} & \multirow{2}{*}{11} & $\begin{array}{c}1.01 \\
(0.91,1.13)\end{array}$ & $\begin{array}{c}1.07 \\
(0.96,1.19)\end{array}$ & $\begin{array}{c}1.10 \\
(0.95,1.28)\end{array}$ \\
\hline S-Methadone & & & & & $\begin{array}{c}0.96 \\
(0.87,1.06)\end{array}$ & $\begin{array}{c}1.00 \\
(0.89,1.12)\end{array}$ & $\begin{array}{c}1.02 \\
(0.89,1.17)\end{array}$ \\
\hline Sertraline & 50 single dose & $\begin{array}{l}150 \text { once } \\
\text { daily }^{c}\end{array}$ & $\begin{array}{l}150 \text { once } \\
\text { daily }^{c}\end{array}$ & 19 & $\begin{array}{c}1.14 \\
(0.94,1.38)\end{array}$ & $\begin{array}{c}0.93 \\
(0.77,1.13)\end{array}$ & N/A \\
\hline
\end{tabular}




\begin{tabular}{|c|c|c|c|c|c|c|c|}
\hline Rifabutin & \multirow{2}{*}{$\begin{array}{c}150 \text { once every } \\
\text { other day }\end{array}$} & \multirow{2}{*}{$\begin{array}{l}150 \text { once } \\
\text { daily }\end{array}$} & \multirow{2}{*}{$\begin{array}{c}150 \text { once } \\
\text { daily }\end{array}$} & 12 & $\begin{array}{c}1.09 \\
(0.98,1.20)^{\mathrm{e}}\end{array}$ & $\begin{array}{c}0.92 \\
(0.83,1.03)^{\mathrm{e}}\end{array}$ & $\begin{array}{c}0.94 \\
(0.85,1.04)^{\mathrm{e}}\end{array}$ \\
\hline $\begin{array}{l}\text { 25-O-desacetyl- } \\
\text { rifabutin }\end{array}$ & & & & 12 & $\begin{array}{c}4.84 \\
(4.09,5.74)^{\mathrm{e}}\end{array}$ & $\begin{array}{c}6.25 \\
(5.08,7.69)^{\mathrm{e}}\end{array}$ & $\begin{array}{c}4.94 \\
(4.04,6.04)^{\mathrm{e}}\end{array}$ \\
\hline Rosuvastatin & 10 single dose & $\begin{array}{c}150 \text { once } \\
\text { daily }\end{array}$ & $\begin{array}{c}150 \text { once } \\
\text { daily }\end{array}$ & 10 & $\begin{array}{c}1.89 \\
(1.48,2.42)\end{array}$ & $\begin{array}{c}1.38 \\
(1.14,1.67)\end{array}$ & NC \\
\hline Sofosbuvir & \multirow{2}{*}{400 once daily } & \multirow{3}{*}{$\begin{array}{l}150 \text { once } \\
\text { daily }^{c}\end{array}$} & \multirow{3}{*}{$\begin{array}{l}150 \text { once } \\
\text { daily }^{c}\end{array}$} & \multirow{3}{*}{24} & $\begin{array}{c}1.23 \\
(1.07,1.42)\end{array}$ & $\begin{array}{c}1.37 \\
(1.24,1.52)\end{array}$ & $\mathrm{N} / \mathrm{A}$ \\
\hline GS-331007 & & & & & $\begin{array}{c}1.29 \\
(1.25,1.33)\end{array}$ & $\begin{array}{c}1.48 \\
(1.43,1.53)\end{array}$ & $\begin{array}{c}1.58 \\
(1.52,1.65)\end{array}$ \\
\hline Velpatasvir & 100 once daily & & & & $\begin{array}{c}1.30 \\
(1.17,1.45)\end{array}$ & $\begin{array}{c}1.50 \\
(1.35,1.66)\end{array}$ & $\begin{array}{c}1.60 \\
(1.44,1.78)\end{array}$ \\
\hline
\end{tabular}

N/A $=$ Not Applicable $; \mathrm{NC}=$ Not Calculated

a. All interaction studies conducted in healthy volunteers.

b. The predominant circulating inactive metabolite of sofosbuvir.

c. Study conducted with GENVOYA.

d. Study conducted with STRIBILD.

e. Comparison based on rifabutin $300 \mathrm{mg}$ once daily.

\subsection{Microbiology}

\section{Mechanism of Action}

Elvitegravir: Elvitegravir inhibits the strand transfer activity of HIV-1 integrase (integrase strand transfer inhibitor; INSTI), an HIV-1 encoded enzyme that is required for viral replication. Inhibition of integrase prevents the integration of HIV-1 DNA into host genomic DNA, blocking the formation of the HIV-1 provirus and propagation of the viral infection. Elvitegravir does not inhibit human topoisomerases I or II.

Cobicistat: Cobicistat is a selective, mechanism-based inhibitor of cytochromes P450 of the CYP3A subfamily. Inhibition of CYP3A-mediated metabolism by cobicistat enhances the systemic exposure of CYP3A substrates, such as elvitegravir, where bioavailability is limited and half-life is shortened by CYP3A-dependent metabolism.

Emtricitabine: Emtricitabine, a synthetic nucleoside analog of cytidine, is phosphorylated by cellular enzymes to form emtricitabine 5'-triphosphate. Emtricitabine 5'-triphosphate inhibits the activity of the HIV-1 reverse transcriptase by competing with the natural substrate deoxycytidine 5'-triphosphate and by being incorporated into nascent viral DNA which results in chain termination. Emtricitabine 5'-triphosphate is a weak inhibitor of mammalian DNA polymerases $\alpha, \beta, \varepsilon$, and mitochondrial DNA polymerase $\gamma$.

Tenofovir Alafenamide (TAF): TAF is a phosphonamidate prodrug of tenofovir (2'deoxyadenosine monophosphate analog). Plasma exposure to TAF allows for permeation into cells and then TAF is intracellularly converted to tenofovir through hydrolysis by cathepsin A. Tenofovir is subsequently phosphorylated by cellular kinases to the active metabolite tenofovir diphosphate. Tenofovir diphosphate inhibits HIV-1 
replication through incorporation into viral DNA by the HIV reverse transcriptase, which results in DNA chain-termination.

Tenofovir has activity that is specific to human immunodeficiency virus and hepatitis B virus. Cell culture studies have shown that both emtricitabine and tenofovir can be fully phosphorylated when combined in cells. Tenofovir diphosphate is a weak inhibitor of mammalian DNA polymerases that include mitochondrial DNA polymerase $y$ and there is no evidence of toxicity to mitochondria in cell culture.

Antiviral Activity in Cell Culture

Elvitegravir, Cobicistat, Emtricitabine, and Tenofovir Alafenamide (TAF): The combination of elvitegravir, emtricitabine, and TAF was not antagonistic in cell culture combination antiviral activity assays and was not affected by the addition of cobicistat. In addition, elvitegravir, cobicistat, emtricitabine, and TAF were not antagonistic with a panel of representatives from the major classes of approved anti-HIV-1 agents (INSTIs, NNRTIs, NRTIs, and PIs).

Elvitegravir: The antiviral activity of elvitegravir against laboratory and clinical isolates of HIV-1 was assessed in T lymphoblastoid cell lines, monocyte/macrophage cells, and primary peripheral blood lymphocytes. The $50 \%$ effective concentrations $\left(E_{50}\right)$ ranged from 0.02 to $1.7 \mathrm{nM}$. Elvitegravir displayed antiviral activity in cell culture against HIV-1 clades $A, B, C, D, E, F, G$, and $O\left(E_{50}\right.$ values ranged from 0.1 to $1.3 \mathrm{nM}$ ) and activity against HIV-2 $\left(E_{50}\right.$ value of $\left.0.53 \mathrm{nM}\right)$. Elvitegravir did not show inhibition of replication of HBV or HCV in cell culture.

Cobicistat: Cobicistat has no detectable antiviral activity in cell culture against HIV-1, $\mathrm{HBV}$, or $\mathrm{HCV}$ and does not antagonize the antiviral activity of elvitegravir, emtricitabine, or tenofovir.

Emtricitabine: The antiviral activity of emtricitabine against laboratory and clinical isolates of HIV-1 was assessed in T lymphoblastoid cell lines, the MAGI-CCR5 cell line, and primary peripheral blood mononuclear cells. The $\mathrm{EC}_{50}$ values for emtricitabine were in the range of 0.0013-0.64 microM. Emtricitabine displayed antiviral activity in cell culture against HIV-1 clades $A, B, C, D, E, F$, and $G\left(E_{50}\right.$ values ranged from $0.007-$ 0.075 microM) and showed strain specific activity against HIV-2 ( $E C_{50}$ values ranged from $0.007-1.5$ microM).

Tenofovir Alafenamide (TAF): The antiviral activity of TAF against laboratory and clinical isolates of HIV-1 subtype B was assessed in lymphoblastoid cell lines, PBMCs, primary monocyte/macrophage cells and CD4-T lymphocytes. The $\mathrm{EC}_{50}$ values for TAF ranged from 2.0 to $14.7 \mathrm{nM}$.

TAF displayed antiviral activity in cell culture against all HIV-1 groups $(\mathrm{M}, \mathrm{N}, \mathrm{O})$, including sub-types $A, B, C, D, E, F$, and $G$ ( $E_{50}$ values ranged from 0.10 to $12.0 \mathrm{nM}$ ) and strain specific activity against HIV-2 ( $E_{50}$ values ranged from 0.91 to $2.63 \mathrm{nM}$ ). 
Resistance

In Cell Culture

Elvitegravir: HIV-1 isolates with reduced susceptibility to elvitegravir have been selected in cell culture. Reduced susceptibility to elvitegravir was associated with the primary integrase substitutions T66A/l, E92G/Q, S147G, and Q148R.

Additional integrase substitutions observed in cell culture selection included D10E, S17N, H51Y, F121Y, S153F/Y, E157Q, D232N, R263K, and V281M.

Emtricitabine: HIV-1 isolates with reduced susceptibility to emtricitabine have been selected in cell culture. Reduced susceptibility to emtricitabine was associated with M184V or I substitutions in HIV-1 RT.

Tenofovir Alafenamide (TAF): HIV-1 isolates with reduced susceptibility to TAF have been selected in cell culture. HIV-1 isolates selected by TAF expressed a K65R substitution in HIV-1 RT, sometimes in the presence of S68N or L429I substitutions; in addition, a K70E substitution in HIV-1 RT was observed.

In Clinical Trials

\section{In Treatment-Naïve Subjects:}

In a pooled analysis of antiretroviral-naïve subjects receiving GENVOYA in Studies 104 and 111, genotyping was performed on plasma HIV-1 isolates from all subjects with HIV-1 RNA greater than 400 copies per $\mathrm{mL}$ at confirmed virologic failure, at Week 96 , or at time of early study drug discontinuation. As of Week 96, the development of genotypic resistance to elvitegravir, emtricitabine, or TAF was observed in 10 of 19 subjects with evaluable resistance data from paired baseline and GENVOYA treatment-failure isolates (10 of 866 subjects [1.2\%]) compared with 9 of 15 treatment-failure isolates from subjects with evaluable resistance data in the STRIBILD treatment group (9 of 867 subjects [1.0\%]). Of the 10 subjects with resistance development in the GENVOYA group, the resistance-associated substitutions that emerged were $\mathrm{M} 184 \mathrm{~V} / \mathrm{I}(\mathrm{N}=9)$ and $\mathrm{K} 65 \mathrm{R} / \mathrm{N}(\mathrm{N}=2)$ in reverse transcriptase and T66T/A/I/N (N=2), E92Q $(\mathrm{N}=4)$, $\mathrm{E} 138 \mathrm{~K}(\mathrm{~N}=1), \mathrm{Q} 148 \mathrm{Q} / \mathrm{R}(\mathrm{N}=1)$ and $\mathrm{N} 155 \mathrm{H}(\mathrm{N}=2)$ in integrase. Of the 9 subjects with resistance development in the STRIBILD group, the resistance-associated substitutions that emerged were $\mathrm{M} 184 \mathrm{~V} / \mathrm{I}(\mathrm{N}=6)$ and $\mathrm{K} 65 \mathrm{R} / \mathrm{N}(\mathrm{N}=3)$ in reverse transcriptase and E92Q $(\mathrm{N}=2), \mathrm{E} 138 \mathrm{~K}(\mathrm{~N}=3), \mathrm{Q} 148 \mathrm{R}(\mathrm{N}=2)$, and $\mathrm{N} 155 \mathrm{H} / \mathrm{S}(\mathrm{N}=2)$ in integrase. In both treatment groups, most subjects who developed substitutions associated with resistance to elvitegravir also developed emtricitabine resistance-associated substitutions. These genotypic resistance results were confirmed by phenotypic analyses.

In Virologically Suppressed Subjects:

One subject was identified with emergent resistance to GENVOYA (M184M/I) out of 4 virologic failure subjects in a clinical study of virologically-suppressed 
subjects who switched from a regimen containing emtricitabine/TDF and a third agent to GENVOYA (Study 109, N=799).

\section{Cross-Resistance}

No cross-resistance has been demonstrated for elvitegravir-resistant HIV-1 isolates and emtricitabine or tenofovir, or for emtricitabine- or tenofovir-resistant isolates and elvitegravir.

Elvitegravir: Cross-resistance has been observed among INSTIs. Elvitegravir-resistant viruses showed varying degrees of cross-resistance in cell culture to raltegravir depending on the type and number of amino acid substitutions in HIV-1 integrase. Of the primary elvitegravir resistance-associated substitutions tested (T66A///K, E92 $\mathrm{G} / \mathrm{Q}$, T97A, S147G, Q148H/K/R, and N155H), all but three (T66I, E92G, and S147G) conferred greater than 1.5 -fold reduced susceptibility to raltegravir (above the biological cutoff for raltegravir) when introduced individually into a wild-type virus by site-directed mutagenesis. Of the primary raltegravir resistance-associated substitutions ( $\mathrm{Y} 143 \mathrm{C} / \mathrm{H} / \mathrm{R}, \mathrm{Q} 148 \mathrm{H} / \mathrm{K} / \mathrm{R}$, and $\mathrm{N} 155 \mathrm{H})$, all but $\mathrm{Y} 143 \mathrm{C} / \mathrm{H}$ conferred greater than 2.5 -fold reductions in susceptibility to elvitegravir (above the biological cutoff for elvitegravir). Some viruses expressing elvitegravir or raltegravir resistance amino acid substitutions maintain susceptibility to dolutegravir.

Emtricitabine: Cross-resistance has been observed among NRTIs. Emtricitabineresistant isolates harboring an M184V/I substitution in HIV-1 RT were cross-resistant to lamivudine. HIV-1 isolates containing the K65R RT substitution, selected in vivo by abacavir, didanosine, and tenofovir, demonstrated reduced susceptibility to inhibition by emtricitabine.

Tenofovir Alafenamide (TAF): Tenofovir resistance substitutions, K65R and K70E, result in reduced susceptibility to abacavir, didanosine, emtricitabine, lamivudine, and tenofovir.

HIV-1 with multiple TAMs (M41L, D67N, K70R, L210W, T215F/Y, K219Q/E/N/R), or multinucleoside resistant HIV-1 with a T69S double insertion mutation or with a Q151M mutation complex including K65R, showed reduced susceptibility to TAF in cell culture.

\section{NONCLINICAL TOXICOLOGY}

\subsection{Carcinogenesis, Mutagenesis, Impairment of Fertility}

\section{Elvitegravir}

Long-term carcinogenicity studies of elvitegravir were carried out in mice (104 weeks) and in rats for up to 88 weeks (males) and 90 weeks (females). No drug-related increases in tumor incidence were found in mice at doses up to $2000 \mathrm{mg}$ per kg per day alone or in combination with $25 \mathrm{mg}$ per kg per day RTV at exposures 3- and 14 times, respectively, the human systemic exposure at the recommended daily dose of $150 \mathrm{mg}$. No drug-related increases in tumor incidence were found in rats at doses up to $2000 \mathrm{mg}$ 
per kg per day at exposures 12- to 27 times, respectively in male and female, the human systemic exposure.

Elvitegravir was not genotoxic in the reverse mutation bacterial test (Ames test) and the rat micronucleus assay. In an in vitro chromosomal aberration test, elvitegravir was negative with metabolic activation; however, an equivocal response was observed without activation.

Elvitegravir did not affect fertility in male and female rats at approximately 16- and 30 times higher exposures (AUC), respectively, than in humans at the recommended 150 mg daily dose.

Fertility was normal in the offspring of rats exposed daily from before birth (in utero) through sexual maturity at daily exposures (AUC) of approximately 18 times higher than human exposures at the recommended $150 \mathrm{mg}$ daily dose.

\section{Cobicistat}

In a long-term carcinogenicity study in mice, no drug-related increases in tumor incidence were observed at doses up to 50 and $100 \mathrm{mg} / \mathrm{kg} /$ day (males and females, respectively). Cobicistat exposures at these doses were approximately 7 (male) and 16 (females) times, respectively, the human systemic exposure at the therapeutic daily dose. In a long-term carcinogenicity study of cobicistat in rats, an increased incidence of follicular cell adenomas and/or carcinomas in the thyroid gland was observed at doses of 25 and $50 \mathrm{mg} / \mathrm{kg} /$ day in males, and at $30 \mathrm{mg} / \mathrm{kg} / \mathrm{day}$ in females. The follicular cell findings are considered to be rat-specific, secondary to hepatic microsomal enzyme induction and thyroid hormone imbalance, and are not relevant for humans. At the highest doses tested in the rat carcinogenicity study, systemic exposures were approximately 2 times the human systemic exposure at the recommended daily dose.

Cobicistat was not genotoxic in the reverse mutation bacterial test (Ames test), mouse lymphoma or rat micronucleus assays.

Cobicistat did not affect fertility in male or female rats at daily exposures (AUC) approximately 4 times higher than human exposures at the recommended $150 \mathrm{mg}$ daily dose.

Fertility was normal in the offspring of rats exposed daily from before birth (in utero) through sexual maturity at daily exposures (AUC) of approximately 1.2 times higher than human exposures at the recommended $150 \mathrm{mg}$ daily dose.

\section{Emtricitabine}

In long-term carcinogenicity studies of emtricitabine, no drug-related increases in tumor incidence were found in mice at doses up to $750 \mathrm{mg}$ per $\mathrm{kg}$ per day (23 times the human systemic exposure at the therapeutic dose of $200 \mathrm{mg}$ per day) or in rats at doses up to $600 \mathrm{mg}$ per $\mathrm{kg}$ per day (28 times the human systemic exposure at the recommended dose). 
Emtricitabine was not genotoxic in the reverse mutation bacterial test (Ames test), mouse lymphoma or mouse micronucleus assays.

Emtricitabine did not affect fertility in male rats at approximately 140 times or in male and female mice at approximately 60 times higher exposures (AUC) than in humans given the recommended $200 \mathrm{mg}$ daily dose. Fertility was normal in the offspring of mice exposed daily from before birth (in utero) through sexual maturity at daily exposures (AUC) of approximately 60 times higher than human exposures at the recommended $200 \mathrm{mg}$ daily dose.

\section{Tenofovir Alafenamide (TAF)}

Since TAF is rapidly converted to tenofovir and a lower tenofovir exposure in rats and mice is observed after TAF administration compared to TDF administration, carcinogenicity studies were conducted only with TDF. Long-term oral carcinogenicity studies of TDF in mice and rats were carried out at exposures up to approximately 10 times (mice) and 4 times (rats) those observed in humans at the $300 \mathrm{mg}$ therapeutic dose of TDF for HIV-1 infection. The tenofovir exposure in these studies was approximately 167 times (mice) and 55 times (rat) those observed in humans after administration of GENVOYA treatment. At the high dose in female mice, liver adenomas were increased at tenofovir exposures 10 times (300 mg TDF) and 167 times (10 mg TAF in GENVOYA) that in humans. In rats, the study was negative for carcinogenic findings.

TAF was not genotoxic in the reverse mutation bacterial test (Ames test), mouse lymphoma or rat micronucleus assays.

There were no effects on fertility, mating performance or early embryonic development when TAF was administered to male rats at a dose equivalent to 155 times the human dose based on body surface area comparisons for 28 days prior to mating and to female rats for 14 days prior to mating through Day 7 of gestation.

\subsection{Animal Toxicology and/or Pharmacology}

Minimal to slight infiltration of mononuclear cells in the posterior uvea was observed in dogs with similar severity after three and nine month administration of TAF; reversibility was seen after a three month recovery period. At the NOAEL for eye toxicity, the systemic exposure in dogs was 5 (TAF) and 15 (tenofovir) times the exposure seen in humans at the recommended daily GENVOYA dosage.

\section{CLINICAL STUDIES}

\subsection{Description of Clinical Trials}

The efficacy and safety of GENVOYA were evaluated in the studies summarized in Table 12. 
Table 12 Trials Conducted with GENVOYA in Subjects with HIV-1 Infection

\begin{tabular}{|c|c|c|c|}
\hline Trial & Population & Study Arms (N) & $\begin{array}{c}\text { Timepoint } \\
\text { (Week) }\end{array}$ \\
\hline $\begin{array}{l}\text { Study } 104^{a} \\
\text { Study } 111^{a}\end{array}$ & $\begin{array}{l}\text { Treatment-naïve } \\
\text { adults }\end{array}$ & $\begin{array}{l}\text { GENVOYA (866) } \\
\text { STRIBILD (867) }\end{array}$ & 96 \\
\hline Study $109^{b}$ & $\begin{array}{c}\text { Virologically- } \\
\text { suppressed }^{d} \text { adults }\end{array}$ & $\begin{array}{c}\text { GENVOYA (799) } \\
\text { ATRIPLA }{ }^{\circledR} \text { or } \\
\text { TRUVADA }^{\circledR}+\text { atazanavir+cobicistat } \\
\text { or ritonavir or STRIBILD (397) }\end{array}$ & 48 \\
\hline Study $112^{c}$ & $\begin{array}{c}\text { Virologically- } \\
\text { suppressed }{ }^{d} \text { adults } \\
\text { with renal impairment }\end{array}$ & GENVOYA (242) & 96 \\
\hline Study $106^{\mathrm{C}}$ & $\begin{array}{l}\text { Treatment-naïve } \\
\text { adolescents between } \\
\text { the ages of } 12 \text { to less } \\
\text { than } 18 \text { years }\end{array}$ & GENVOYA (23) & 24 \\
\hline
\end{tabular}

a. Randomized, double blind, active controlled trial.

b. Randomized, open label, active controlled trial.

c. Open label trial.

d. HIV-1 RNA less than 50 copies per $\mathrm{mL}$.

e. eGFR of 30 to $69 \mathrm{~mL}$ per minute by Cockcroft-Gault method.

\subsection{Clinical Trial Results in HIV-1 Treatment-Naïve Subjects}

In both Study 104 and Study 111, subjects were randomized in a 1:1 ratio to receive either GENVOYA ( $\mathrm{N}=866$ ) once daily or STRIBILD (elvitegravir $150 \mathrm{mg}$, cobicistat 150 $\mathrm{mg}$, emtricitabine $200 \mathrm{mg}$, TDF $300 \mathrm{mg})(\mathrm{N}=867)$ once daily. The mean age was 36 years (range $18-76$ ), $85 \%$ were male, $57 \%$ were White, $25 \%$ were Black, and $10 \%$ were Asian. Nineteen percent of subjects identified as Hispanic/Latino. The mean baseline plasma HIV-1 RNA was $4.5 \log _{10}$ copies per $\mathrm{mL}$ (range $1.3-7.0$ ) and $23 \%$ of subjects had baseline viral loads greater than 100,000 copies per $\mathrm{mL}$. The mean baseline CD4+ cell count was 427 cells per $\mathrm{mm}^{3}$ (range $0-1360$ ) and $13 \%$ had CD4+ cell counts less than 200 cells per $\mathrm{mm}^{3}$.

Pooled treatment outcomes of Studies 104 and 111 through Week 96 are presented in Table 13. 
Table 13 Pooled Virologic Outcomes of Randomized Treatment in Studies 104 and 111 at Week $96^{\mathrm{a}}$ in Treatment-Naïve Subjects

\begin{tabular}{|c|c|c|}
\hline & \multicolumn{1}{|c|}{$\begin{array}{c}\text { GENVOYA } \\
\text { (N=866) }\end{array}$} & $\begin{array}{c}\text { STRIBILD } \\
\text { (N=867) }\end{array}$ \\
\hline HIV-1 RNA < 50 copies/mL & $87 \%$ & $85 \%$ \\
\hline Treatment Difference & $1.5 \%(95 \%$ Cl: $-1.7 \%$ to $4.8 \%)$ \\
\hline HIV-1 RNA $\geq \mathbf{5 0}$ copies/mL ${ }^{\mathrm{b}}$ & $5 \%$ & $4 \%$ \\
\hline $\begin{array}{l}\text { No Virologic Data at Week } \mathbf{9 6} \\
\text { Window }\end{array}$ & $9 \%$ & $11 \%$ \\
\hline $\begin{array}{l}\text { Discontinued Study Drug Due to } \\
\text { AE or Death }\end{array}$ & $1 \%$ & $2 \%$ \\
\hline $\begin{array}{l}\text { Discontinued Study Drug Due to } \\
\text { Other Reasons and Last Available } \\
\text { HIV-1 RNA < 50 copies/mL }\end{array}$ & $6 \%$ & $7 \%$ \\
\hline $\begin{array}{l}\text { dissing Data During Window but } \\
\text { on Study Drug }\end{array}$ & $2 \%$ & $1 \%$ \\
\hline
\end{tabular}

a. Week 96 window was between Day 630 and 713 (inclusive).

b. Included subjects who had $\geq 50$ copies $/ \mathrm{mL}$ in the Week 96 window; subjects who discontinued early due to lack or loss of efficacy; subjects who discontinued for reasons other than an adverse event (AE), death or lack or loss of efficacy and at the time of discontinuation had a viral value of $\geq 50$ copies $/ \mathrm{mL}$.

c. Includes subjects who discontinued due to AE or death at any time point from Day 1 through the time window if this resulted in no virologic data on treatment during the specified window.

d. Includes subjects who discontinued for reasons other than an AE, death or lack or loss of efficacy; e.g., withdrew consent, loss to follow-up, etc.

Treatment outcomes were similar across subgroups by age, sex, race, baseline viral load, and baseline CD4+ cell count.

In Studies 104 and 111, the mean increase from baseline in CD4+ cell count at Week 96 was 280 cells per $\mathrm{mm}^{3}$ in GENVOYA-treated subjects and 266 cells per $\mathrm{mm}^{3}$ in STRIBILD-treated subjects.

\subsection{Clinical Trial Results in HIV-1 Virologically-Suppressed Subjects Who Switched to GENVOYA}

In Study 109, the efficacy and safety of switching from either ATRIPLA, TRUVADA plus atazanavir (given with either cobicistat or ritonavir), or STRIBILD to GENVOYA once daily were evaluated in a randomized, open-label trial of virologically-suppressed (HIV-1 RNA less than 50 copies per $\mathrm{mL}$ ) HIV-1 infected adults (1196 of 1436 enrolled and treated were evaluable for efficacy). Subjects must have been suppressed (HIV-1 RNA less than 50 copies per $\mathrm{mL}$ ) on their baseline regimen for at least 6 months and had no known resistance-associated substitutions to any of the components of GENVOYA prior to study entry. Subjects were randomized in a 2:1 ratio to either switch to GENVOYA at baseline $(\mathrm{N}=799)$, or stay on their baseline antiretroviral regimen $(\mathrm{N}=397)$. Subjects had a mean age of 41 years (range $21-72$ ), $90 \%$ were male, $67 \%$ were White, and $21 \%$ 
were Black. The mean baseline CD4+ cell count was 705 cells per $\mathrm{mm}^{3}$ (range 79 1951).

Subjects were stratified by prior treatment regimen. At screening, $42 \%$ of subjects were receiving TRUVADA plus atazanavir (given with either cobicistat or ritonavir), $32 \%$ were receiving STRIBILD, and $26 \%$ were receiving ATRIPLA.

Treatment outcomes of Study 109 through 48 weeks are presented in Table 14.

Table 14 Virologic Outcomes of Study 109 at Week $48^{a}$ in VirologicallySuppressed Subjects who Switched to GENVOYA

\begin{tabular}{|l|c|c|}
\hline & & $\begin{array}{c}\text { ATRIPLA or } \\
\text { TRUVADA+atazanavir } \\
\text { +cobicistat or ritonavir } \\
\text { or STRIBILD } \\
\text { (N=397) }\end{array}$ \\
\hline HIV-1 RNA < 50 copies/mL & $96 \%$ & $93 \%$ \\
\hline HIV-1 RNA $\geq \mathbf{5 0}$ copies/mL ${ }^{\mathbf{b}}$ & $1 \%$ & $1 \%$ \\
\hline No Virologic Data at Week $\mathbf{4 8}$ Window & $3 \%$ & $6 \%$ \\
\hline $\begin{array}{l}\text { Discontinued Study Drug Due to AE or } \\
\text { Death }\end{array}$ & $1 \%$ & $1 \%$ \\
\hline $\begin{array}{l}\text { Discontinued Study Drug Due to Other } \\
\text { Reasons and Last Available HIV-1 RNA } \\
<50 \text { copies/mL }\end{array}$ & $1 \%$ & $4 \%$ \\
\hline $\begin{array}{l}\text { dissing Data During Window but on } \\
\text { Study Drug }\end{array}$ & $2 \%$ & $1 \%$ \\
\hline
\end{tabular}

a. Week 48 window was between Day 294 and 377 (inclusive).

b. Included subjects who had $\geq 50$ copies $/ \mathrm{mL}$ in the Week 48 window; subjects who discontinued early due to lack or loss of efficacy; subjects who discontinued for reasons other than an adverse event (AE), death or lack or loss of efficacy and at the time of discontinuation had a viral value of $\geq 50 \mathrm{copies} / \mathrm{mL}$.

c. Includes subjects who discontinued due to $A E$ or death at any time point from Day 1 through the time window if this resulted in no virologic data on treatment during the specified window.

d. Includes subjects who discontinued for reasons other than an AE, death or lack or loss of efficacy; e.g., withdrew consent, loss to follow-up, etc.

Treatment outcomes were similar across subgroups receiving ATRIPLA, TRUVADA plus atazanavir (given with either cobicistat or ritonavir), or STRIBILD prior to randomization. In Study 109, the mean increase from baseline in CD4+ cell count at Week 48 was 33 cells per $\mathrm{mm}^{3}$ in GENVOYA-treated subjects and 27 cells per $\mathrm{mm}^{3}$ in subjects who stayed on their baseline regimen.

\subsection{Clinical Trial Results in HIV-1 Infected Subjects with Renal Impairment}

In Study 112, the efficacy and safety of GENVOYA once daily were evaluated in an open-label clinical trial of $248 \mathrm{HIV}-1$ infected subjects with renal impairment (eGFR of 30 to $69 \mathrm{~mL}$ per minute by Cockcroft-Gault method). Of the 248 enrolled, 6 were treatment-naïve and 242 were virologically suppressed (HIV-1 RNA less than 50 copies 
per $\mathrm{mL}$ ) for at least 6 months before switching to GENVOYA [see Use in Specific Populations (8.6) and Clinical Pharmacology (12.3)].

The mean age was 58 years (range 24-82), with 63 subjects (26\%) who were 65 years of age or older. Seventy-nine percent were male, $63 \%$ were White, $18 \%$ were Black, and $14 \%$ were Asian. Thirteen percent of subjects identified as Hispanic/Latino. The mean baseline CD4+ cell count was 664 cells per $\mathrm{mm}^{3}$ (range 126-1813). At Week 96, $88 \%(214 / 242$ virologically suppressed subjects) maintained HIV-1 RNA less than 50 copies per $\mathrm{mL}$ after switching to GENVOYA. All six treatment-naïve subjects were virologically suppressed at Week 96 . Five subjects among the entire study population had virologic failure at Week 96.

\subsection{Clinical Trial Results in HIV-1 Treatment-Naïve Adolescent Subjects Aged 12 to Less than 18}

In Study 106, the efficacy, safety, and pharmacokinetics of GENVOYA were evaluated in an open-label trial in HIV-1 infected treatment-naïve adolescents aged 12 to less than 18 years weighing at least $35 \mathrm{~kg}$ (77 lbs). Twenty-three subjects treated with GENVOYA once daily for 24 weeks had a mean age of 14 years; $52 \%$ were male, $17 \%$ were Asian, and $83 \%$ were black. At baseline, mean plasma HIV-1 RNA was $4.8 \log _{10}$ copies per $\mathrm{mL}$ ( $35 \%$ had baseline plasma HIV-1 RNA greater than 100,000 copies per $\mathrm{mL}$ ), median CD4+ cell count was 456 cells per $\mathrm{mm}^{3}$ (range: 104 to 748 ), and median CD4+ percentage was $23 \%$ (range: $7 \%$ to $41 \%$ ).

At 24 weeks, the virologic response rate to GENVOYA in treatment-naïve HIV-1 infected adolescents was similar to response rates in trials of treatment-naïve HIV-1 infected adults; $91 \%$ achieved HIV-1 RNA less than 50 copies per $\mathrm{mL}$. The mean increase from baseline in CD4+ cell count at Week 24 was 212 cells per $\mathrm{mm}^{3}$. Two subjects had virologic failure at Week 24; neither subject had evidence of resistance to GENVOYA.

\section{HOW SUPPLIED/STORAGE AND HANDLING}

GENVOYA tablets are green, capsule-shaped, film-coated tablets, debossed with "GSI" on one side of the tablet and the number " 510 " on the other side. Each bottle contains 30 tablets (NDC 61958-1901-1), a silica gel desiccant, polyester coil, and is closed with a child-resistant closure.

Store below $30^{\circ} \mathrm{C}\left(86^{\circ} \mathrm{F}\right)$.

- Keep container tightly closed.

- Dispense only in original container.

\section{PATIENT COUNSELING INFORMATION}

Advise the patient to read the FDA-approved patient labeling (Patient Information). 


\section{Drug Interactions}

GENVOYA may interact with many drugs; therefore, advise patients to report to their healthcare provider the use of any other prescription or non-prescription medication or herbal products including St. John's wort [see Contraindications (4) and Drug Interactions (7)].

\section{Lactic Acidosis}

Lactic acidosis and severe hepatomegaly with steatosis, including fatal cases, have been reported with use of drugs similar to GENVOYA. Advise patients that they should stop GENVOYA if they develop clinical symptoms suggestive of lactic acidosis or pronounced hepatotoxicity [see Warnings and Precautions (5.1)].

\section{Post-treatment Acute Exacerbation of Hepatitis B in Patients with HBV Co-Infection}

Severe acute exacerbations of hepatitis $B$ have been reported in patients who are coinfected with HBV and HIV-1 and have discontinued products containing emtricitabine and/or TDF, and may likewise occur with discontinuation of GENVOYA [see Warnings and Precautions (5.2)]. Advise the patient to not discontinue GENVOYA without first informing their healthcare provider.

\section{Fat Redistribution}

Inform patients that redistribution or accumulation of body fat may occur in patients receiving antiretroviral therapy and that the cause and long-term health effects of these conditions are not known [see Warnings and Precautions (5.4)].

\section{Immune Reconstitution Syndrome}

Advise patients to inform their healthcare provider immediately of any symptoms of infection, as in some patients with advanced HIV infection (AIDS), signs and symptoms of inflammation from previous infections may occur soon after anti-HIV treatment is started [see Warnings and Precautions (5.5)].

\section{$\underline{\text { Renal Impairment }}$}

Advise patients to avoid taking GENVOYA with concurrent or recent use of nephrotoxic agents. Renal impairment including cases of acute renal failure has been reported in association with the use of tenofovir prodrugs [see Warnings and Precautions (5.6)].

\section{Missed Dosage}

Inform patients that it is important to take GENVOYA on a regular dosing schedule with food and to avoid missing doses as it can result in development of resistance [see Dosage and Administration (2.2)]. 


\section{Pregnancy Registry}

Inform patients that there is an antiretroviral pregnancy registry to monitor fetal outcomes of pregnant women exposed to GENVOYA [see Use in Specific Populations (8.1)].

\section{Lactation}

Instruct women with HIV-1 infection not to breastfeed because HIV-1 can be passed to the baby in breast milk [see Use in Specific Populations (8.2)].

Manufactured and distributed by: Gilead Sciences, Inc. Foster City, CA 94404 


\section{Patient Information \\ GENVOYA $^{\circledR}$ (jen-VOY-uh) \\ (elvitegravir, cobicistat, emtricitabine, \\ and tenofovir alafenamide) \\ tablets}

Important: Ask your healthcare provider or pharmacist about medicines that should not be taken with

GENVOYA. For more information, see the section "What should I tell my healthcare provider before taking GENVOYA?"

Read this Patient Information before you start taking GENVOYA and each time you get a refill. There may be new information. This information does not take the place of talking with your healthcare provider about your medical condition or treatment.

What is the most important information I should know about GENVOYA?

GENVOYA can cause serious side effects, including:

1. Build-up of lactic acid in your blood (lactic acidosis). Lactic acidosis may happen in some people who take GENVOYA or similar medicines. Lactic acidosis is a serious medical emergency that can lead to death.

Lactic acidosis can be hard to identify early, because the symptoms could seem like symptoms of other health problems. Call your healthcare provider right away if you get any of the following symptoms which could be signs of lactic acidosis:

- feel very weak or tired

- have unusual (not normal) muscle pain

- have trouble breathing

- have stomach pain with nausea or vomiting

2. Severe liver problems. Severe liver problems may happen in people who take GENVOYA. In some cases, these liver problems can lead to death. Your liver may become large (hepatomegaly) and you may develop fat in your liver (steatosis).

Call your healthcare provider right away if you get any of the following symptoms of liver problems:

- your skin or the white part of your eyes turns yellow (jaundice)

- dark "tea-colored" urine

- light-colored bowel movements (stools)

- loss of appetite
- feel cold, especially in your arms and legs

- feel dizzy or lightheaded

- have a fast or irregular heartbeat

You may be more likely to get lactic acidosis or severe liver problems if you are female, very overweight (obese), or have been taking GENVOYA or a similar medicine for a long time.

3. Worsening of Hepatitis $B$ infection. GENVOYA is not for use to treat chronic hepatitis B virus (HBV) infection. If you have hepatitis B virus (HBV) infection and take GENVOYA, your HBV may get worse (flareup) if you stop taking GENVOYA. A "flare-up" is when your HBV infection suddenly returns in a worse way than before.

- Do not run out of GENVOYA. Refill your prescription or talk to your healthcare provider before your GENVOYA is all gone.

- Do not stop taking GENVOYA without first talking to your healthcare provider.

- If you stop taking GENVOYA, your healthcare provider will need to check your health often and do blood tests regularly for several months to check your HBV infection. Tell your healthcare provider about any new or unusual symptoms you may have after you stop taking GENVOYA.

For more information about side effects, see the section "What are the possible side effects of GENVOYA?" 


\section{What is GENVOYA?}

GENVOYA is a prescription medicine that is used without other antiretroviral medicines to treat Human Immunodeficiency Virus-1 (HIV-1) in people 12 years of age and older:

- who have not received anti-HIV-1 medicines in the past, or

- to replace their current anti-HIV-1 medicines for people whose healthcare provider determines that they meet certain requirements.

HIV-1 is the virus that causes AIDS (Acquired Immune Deficiency Syndrome).

GENVOYA contains the prescription medicines elvitegravir $\left(\right.$ VITEKTA $\left.^{\circledR}\right)$, cobicistat $\left(\right.$ TYBOST $\left.^{\circledR}\right)$, emtricitabine $\left(\right.$ EMTRIVA $\left.^{\circledR}\right)$ and tenofovir alafenamide.

It is not known if GENVOYA is safe and effective in children under 12 years of age or who weigh less than $77 \mathrm{lbs}$.

\section{Who should not take GENVOYA?}

Do not take GENVOYA if you also take a medicine that contains:

- alfuzosin hydrochloride (UROXATRAL ${ }^{\circledR}$ )

- $\quad$ carbamazepine $\left(\mathrm{CARBATROL}^{\circledR}, \mathrm{EPITOL}^{\circledR}, \mathrm{EQUETRO}^{\circledR}\right.$, TEGRETOL $^{\circledR}$, TEGRETOL-XR $^{\circledR}, \mathrm{TERIL}^{\circledR}$ )

- cisapride (PROPULSID ${ }^{\circledR}$, PROPULSID QUICKSOLV ${ }^{\circledR}$ )

- ergot-containing medicines, including:

- dihydroergotamine mesylate (D.H.E. $45^{\circledR}$, MIGRANAL $^{\circledR}$ )

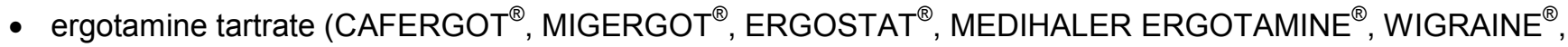
WIGRETTES ${ }^{\circledR}$ )

- methylergonovine maleate (ERGOTRATE ${ }^{\circledR}$, METHERGINE $^{\circledR}$ )

- lovastatin $\left(\right.$ ADVICOR $^{\circledR}$, ALTOPREV $^{\circledR}$, MEVACOR $\left.^{\circledR}\right)$

- lurasidone (LATUDA $\left.{ }^{\circledR}\right)$

- midazolam, when taken by mouth

- $\quad$ phenobarbital $\left(\right.$ LUMINAL $\left.^{\circledR}\right)$

- $\quad$ phenytoin (DILANTIN ${ }^{\circledR}$, PHENYTEK $^{\circledR}$ )

- $\quad$ pimozide $\left(\right.$ ORAP $\left.^{\circledR}\right)$

- $\quad$ rifampin (RIFADIN ${ }^{\circledR}$, RIFAMATE $^{\circledR}$, RIFATER $^{\circledR}$, RIMACTANE $^{\circledR}$ )

- $\quad$ sildenafil $\left(R E V A T I O^{\circledR}\right)$, when used for treating the lung problem, pulmonary arterial hypertension (PAH)

- $\quad$ simvastatin $\left(\right.$ SIMCOR $^{\circledR}$, VYTORIN $^{\circledR}$, ZOCOR $^{\circledR}$ )

- triazolam $\left(\mathrm{HALCION}^{\circledR}\right)$

- St. John's wort (Hypericum perforatum) or a product that contains St. John's wort

\section{What should I tell my healthcare provider before taking GENVOYA?}

Before taking GENVOYA, tell your healthcare provider if you:

- have liver problems, including hepatitis B infection

- have kidney problems

- have any other medical conditions

- are pregnant or plan to become pregnant. It is not known if GENVOYA can harm your unborn baby. Tell your healthcare provider if you become pregnant while taking GENVOYA.

Pregnancy Registry: There is a pregnancy registry for women who take antiviral medicines during pregnancy. The purpose of this registry is to collect information about the health of you and your baby. Talk with your healthcare provider about how you can take part in this registry.

- $\quad$ are breastfeeding or plan to breastfeed. Do not breastfeed if you take GENVOYA.

- You should not breastfeed if you have HIV-1 because of the risk of passing HIV-1 to your baby.

- At least one of the medicines in GENVOYA can pass to your baby in your breast milk. It is not known if the other medicines in GENVOYA can pass into your breast milk.

Talk with your healthcare provider about the best way to feed your baby.

Tell your healthcare provider about all the medicines you take, including prescription and over-the-counter medicines, vitamins, and herbal supplements.

Some medicines may interact with GENVOYA. Keep a list of your medicines and show it to your healthcare provider and 
pharmacist when you get a new medicine.

- You can ask your healthcare provider or pharmacist for a list of medicines that interact with GENVOYA.

- Do not start a new medicine without telling your healthcare provider. Your healthcare provider can tell you if it is safe to take GENVOYA with other medicines.

How should I take GENVOYA?

- Take GENVOYA exactly as your healthcare provider tells you to take it. GENVOYA is taken by itself (not with other HIV-1 medicines) to treat HIV-1 infection.

- Take GENVOYA 1 time each day.

- Take GENVOYA with food.

- Do not change your dose or stop taking GENVOYA without first talking with your healthcare provider. Stay under a healthcare provider's care when taking GENVOYA.

- If you need to take a medicine for indigestion (antacid) that contains aluminum hydroxide, magnesium hydroxide, or calcium carbonate during treatment with GENVOYA, take it at least 2 hours before or after you take GENVOYA.

- Do not miss a dose of GENVOYA.

- If you take too much GENVOYA, call your healthcare provider or go to the nearest hospital emergency room right away.

- When your GENVOYA supply starts to run low, get more from your healthcare provider or pharmacy. This is very important because the amount of virus in your blood may increase if the medicine is stopped for even a short time. The virus may develop resistance to GENVOYA and become harder to treat.

What are the possible side effects of GENVOYA?

GENVOYA may cause serious side effects, including:

- See "What is the most important information I should know about GENVOYA?"

- Changes in body fat can happen in people who take HIV-1 medicine. These changes may include increased amount of fat in the upper back and neck ("buffalo hump"), breast, and around the middle of your body (trunk). Loss of fat from the legs, arms and face may also happen. The exact cause and long-term health effects of these conditions are not known.

- Changes in your immune system (Immune Reconstitution Syndrome) can happen when you start taking HIV-1 medicines. Your immune system may get stronger and begin to fight infections that have been hidden in your body for a long time. Tell your healthcare provider right away if you start having any new symptoms after starting your HIV1 medicine.

- New or worse kidney problems, including kidney failure. Your healthcare provider should do blood and urine tests to check your kidneys before you start and during treatment with GENVOYA. Your healthcare provider may tell you to stop taking GENVOYA if you develop new or worse kidney problems.

The most common side effect of GENVOYA is nausea.

Tell your healthcare provider if you have any side effect that bothers you or that does not go away.

These are not all the possible side effects of GENVOYA. For more information, ask your healthcare provider or pharmacist.

Call your doctor for medical advice about side effects. You may report side effects to FDA at 1-800-FDA-1088.

How should I store GENVOYA?

- Store GENVOYA below $86^{\circ} \mathrm{F}\left(30^{\circ} \mathrm{C}\right)$.

- Keep GENVOYA in its original container.

- Keep the container tightly closed.

Keep GENVOYA and all medicines out of reach of children. 
General information about the safe and effective use of GENVOYA.

Medicines are sometimes prescribed for purposes other than those listed in a Patient Information leaflet. Do not use GENVOYA for a condition for which it was not prescribed. Do not give GENVOYA to other people, even if they have the same symptoms you have. It may harm them. You can ask your healthcare provider or pharmacist for information about GENVOYA that is written for health professionals.

For more information, call 1-800-445-3235 or go to www.GENVOYA.com.

What are the ingredients in GENVOYA?

Active ingredients: elvitegravir, cobicistat, emtricitabine, and tenofovir alafenamide

Inactive ingredients: croscarmellose sodium, hydroxypropyl cellulose, lactose monohydrate, magnesium stearate, microcrystalline cellulose, silicon dioxide, and sodium lauryl sulfate. The tablets are film-coated with a coating material containing FD\&C Blue No. 2/indigo carmine aluminum lake, iron oxide yellow, polyethylene glycol, polyvinyl alcohol, talc, and titanium dioxide.

Manufactured and distributed by: Gilead Sciences, Inc. Foster City, CA 94404

GENVOYA, EMTRIVA, STRIBILD, TRUVADA, TYBOST, and VITEKTA are trademarks of Gilead Sciences, Inc., or its related companies. ATRIPLA is a trademark of BristolMyers Squibb \& Gilead Sciences, LLC. All other trademarks referenced herein are the property of their respective owners.

(C) 2016 Gilead Sciences, Inc. All rights reserved.

207561-GS-004

This Patient Information has been approved by the U.S. Food and Drug Administration.

Revised: $12 / 2016$ 